USE OF SURFACE-GEOPHYSICAL METHODS TO ASSESS RIVERBED SCOUR AT BRIDGE PIERS By S. R. Gorin and F. P. Haeni

U.S. GEOLOGICAL SURVEY

Water-Resources Investigations Report 88-4212

Prepared in cooperation with the

FEDERAL HIGHWAY ADMINISTRATION

Hartford, Connecticut

1989 


\author{
DEPARTMENT OF THE INTERIOR \\ DONALD PAUL HODEL, Secretary \\ U.S. GEOLOGICAL SURVEY \\ Dallas L. Peck, Director
}

For additional information write to:

Chief, Connecticut Office U.S. Geological Survey 450 Main Street, Room 525 Hartford, CT 06103
Copies of this report can

be purchased from:

U.S. Geological Survey

Books and Open-File Reports

Federal Center, Building 810

Box 25425

Denver, CO 80225 


\section{CONTENTS}

Page

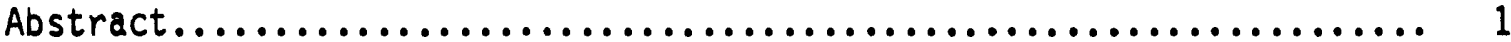

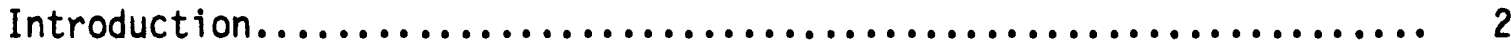

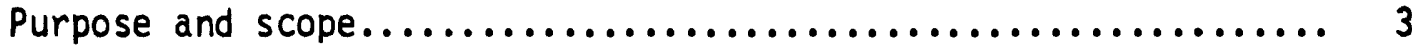

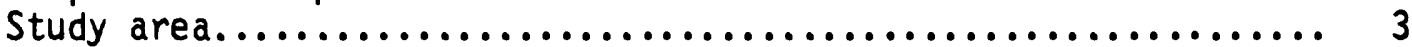

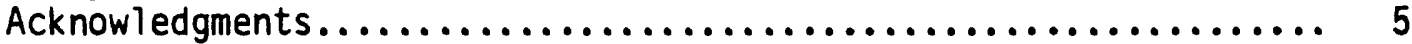

Description of surface-geophysical methods................... 5

Ground-penetrating radar........................... 5

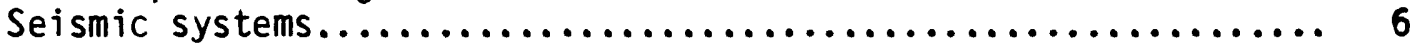

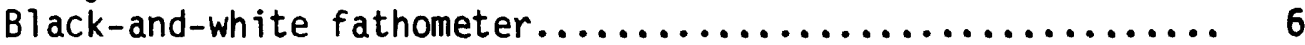

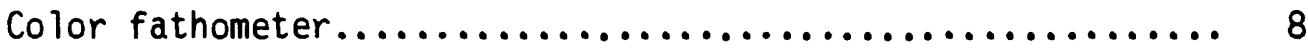

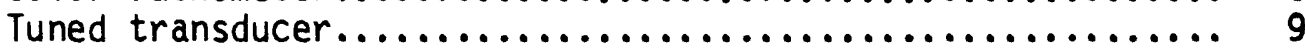

Assessment of riverbed scour $\ldots \ldots \ldots \ldots \ldots \ldots \ldots \ldots \ldots \ldots \ldots \ldots \ldots \ldots \ldots \ldots$

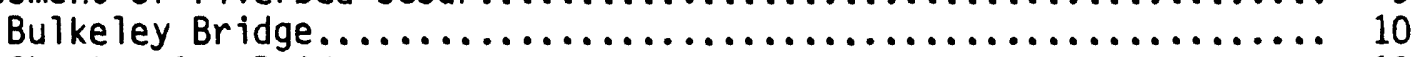

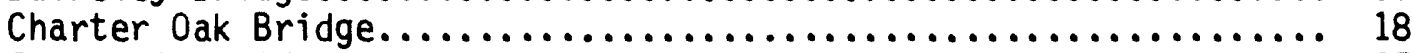

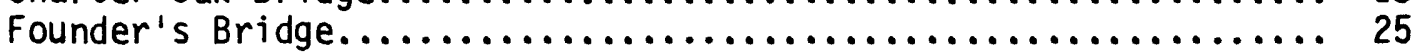

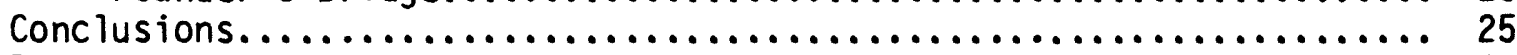

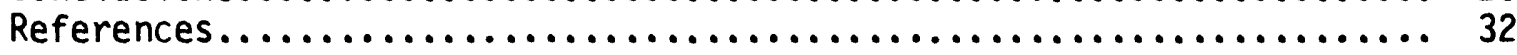

\section{ILLUSTRAT IONS}

Page

Figure 1. Map of the study area...................... 4

2. Record of a ground-penetrating-radar cross section

15 feet upstream from the Bulkeley Bridge............ 11

3. Records of a 200-kilohertz black-and-white fathometer cross section ( 8 feet upstream from the pier) and lateral section ( 6 feet east of the pier) at pier 5

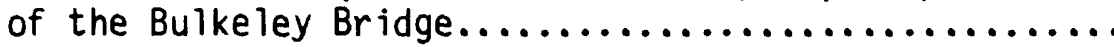

4. Record of a ground-penetrating-radar cross section and interpretation 15 feet upstream from

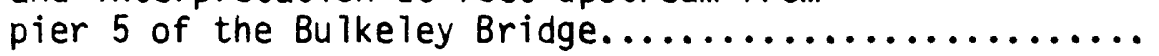

5. Record of a ground-penetrating-radar lateral section 8 feet to the east of pier 5 of the Bulkeley

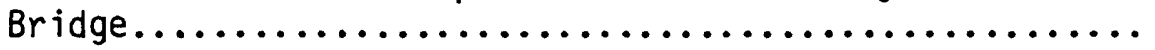

6. Record of a 14-kilohertz tuned-transducer cross section 8 feet upstream from piers 4 and 5

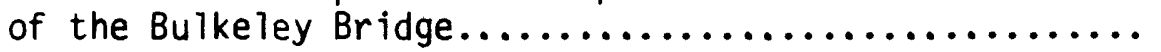


7. Record of a 14-kilohertz tuned-transducer lateral section 10 feet to the east of pier 5 of the Bulkeley Bridge............................... 17

8. Record of a 20-kilohertz color-fathometer cross section 12 feet upstream from pier 5 of the Bulkeley Bridge................................. 19

9. Record of a 20-kilohertz color-fathometer lateral section 8 feet to the east of pier 5 of the Bulkeley Bridge.............................. 20

10. Record of a ground-penetrating-radar cross section 10 feet upstream from the Charter Oak Bridge.......... 21

11. Record of a 200-kilohertz black-and-white fathometer cross section 10 feet upstream from the Charter Oak Bridge.........................

12. Record of a 20-kilohertz color-fathometer lateral section 8 feet to the east of pier 1 of the Charter Oak Bridge........................................

13. Record of a 20-kilohertz color-fathometer cross section 10 feet upstream from the Charter Oak Bridge

14. Record of a 14-kilohertz tuned-transducer cross section 10 feet upstream from the Charter

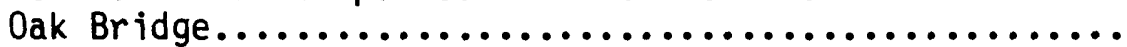

15. Record of a 14-kilohertz tuned-transducer lateral section 8 feet to the east of pier 1 of the Charter Oak Bridge.

16. Record of a ground-penetrating-radar cross section

8 feet upstream from the Founder's Bridge.............. 28

\section{TABLES}

Table 1. Summary of the geophysical methods used to assess riverbed scour at bridge piers. 
For the convenience of readers who prefer metric (International System) units rather than the inch-pound terms in this report, the following conversion factors may be used:

Multiply inch-pound units

by

To obtain metric units

\section{Length}

foot $(\mathrm{ft})$

mile $(\mathrm{mi})$

0.3048

1.609

meter (m)

kilometer $(\mathrm{km})$

Flow

cubic feet per second

$\left(\mathrm{ft}^{3} / \mathrm{s}\right)$

.02832

cubic meter per second

$\left(\mathrm{m}^{3} / \mathrm{s}\right)$

Velocity

feet per nanosecond

0.3048

$(\mathrm{ft} / \mathrm{ns})$

feet per second $(\mathrm{ft} / \mathrm{s}$ )

0.3048

meters per nanosecond

(m/ns)

meters per second $(\mathrm{m} / \mathrm{s})$

\section{Temperature}

degree Fahrenheit ( ${ }^{\circ} \mathrm{F}$ )

${ }^{\circ} \mathrm{C}=5 / 9\left({ }^{\circ} \mathrm{F}-32\right) \quad$ degree Celsius

$\left({ }^{\circ} \mathrm{C}\right)$ 


\title{
USE OF SURFACE-GEOPHYSICAL METHODS \\ TO ASSESS RIVERBED SCOUR AT BRIDGE PIERS
}

\author{
By S. R. Gorin and F. P. Haeni
}

\section{ABSTRACT}

A ground-penetrating-radar system, a black-and-white fathometer, a color fathometer, and a tuned transducer were evaluated for their ability to measure riverbed scour at the Bulkeley, Charter Oak and Founder's Bridges in Hartford, Connecticut. Cross sections and some lateral sections were run at each bridge from June through July 1987, and significant scour at piers supporting each of these bridges was observed. Each of the four geophysical systems proved to have characteristic advantages and disadvantages.

A ground-penetrating-radar system with single and dual 80-megahertz antennae floating in the water was used. It was successful in water less than 25 feet deep and in resistive earth materials. With this geophysical method, the geometry of existing scour holes was clearly defined as was infilling in some holes. Penetration ranged from 1 foot to 20 feet, depending on the physical properties of the riverbed materials, and the resolution of the subbottom layers was 2 feet. This system was effective at distances greater than 3 to 5 feet from the piers.

The black-and-white fathometer was useful for defining existing scour holes. However, at a signal frequency of $200 \mathrm{kilohertz,} \mathrm{it} \mathrm{offered}$ virtually no penetration except in soft muds. This system was effective for obtaining rapid and accurate depth determinations. The black-and-white fathometer was useful in conjunction with other methods for correlation and interpretation of geophysical data, because it substantiated the depth data obtained with other methods.

The color fathometer, operating at a signal frequency of 20 kilohertz, digitized the reflected seismic signals and assigned a color for every 6decibel change in the acoustic impedence of the reflected signals. It delineated the existing scour-hole geometry, detected infilling of scour holes, and provided qualitative information about the physical properties of bottom and subbottom sediments. Side echo became a problem within 5 feet of the piers, and penetration ranged from 2 feet to greater than 20 feet, depending on riverbed materials. This method could not be used in water less than 5 feet deep.

The tuned transducer used in this study operated at a signal frequency of 14 kilohertz. It defined the existing scour-hole geometry and the extent of infilling of soft sediments. Penetration ranged from 2 feet in coarseor hard-packed materials to greater than 30 feet in softer, fine-grained 
sediments. As with the color fathometer, side echo was a problem within 5 feet of the piers, and the method could not be used in water less than 5 feet deep.

\section{INTRODUCTION}

Throughout the past decade, increasing attention has been paid to the problem of riverbed scour at bridge piers. The failure of many bridges throughout the United States may be directly attributed to this problem. In fact, nearly all bridge failures that occur during flood stages are a direct result of scouring around piers (Jarrett and Boyle, 1986; Murillo, 1987). The evaluation of alternative methods for detecting and measuring riverbed scour at bridge piers will aid state and Federal agencies in the development of an effective scour-monitoring program, and an improved understanding of scour and the processes that control it.

Riverbeds are scoured or eroded as a result of the action of flowing water. Total riverbed scour is a combination of three specific scour types-general scour, constriction scour, and local scour (Hopkins and others, 1980; Jarrett and Boyle, 1986). General scour processes are long term, and are a result of changes in the fundamental factors that control channe 1 form. Causes of general scour include changes in sediment supply, changes in flow, and changes in river form. Obstructions such as dams, or increased sediment supply as a result of mining are examples of anthropogenic causes of this type of scour. However, the emplacement of piers during bridge construction is not a direct cause of general scour.

Constriction scour is the result of an increase in water velocity associated with the confinement of flow due to a decreased cross-sectional area. The spaces between bridge piers may be sites for constriction scour. Constriction scour also may occur during high flow at sites where a flood plain has been narrowed through the emplacement of fill during bridge construction. Local scour is the result of disturbances in flow caused by emplaced objects such as pilings and piers. Turbulent flow at bridge piers is the main cause of local scour. The combined problem of general and local scour is one that is particularly pertinent to any study of bridge stability.

One of the greatest obstacles to the study of riverbed scour at bridge piers is the problem of remote monitoring of scour processes. Both local and general scour are most prevalent during flood stages of the river. This is precisely the time when monitoring becomes difficult. Any permanent device for measurement of scour may easily be damaged by flood debris, and navigation of a boat, for measuring scour near bridge piers, during a flood would be very hazardous. Thus, monitoring of riverbed scour at bridge piers becomes most difficult at the time when scour is most prevalent. By using surface-geophysical methods, however, the maximum depth of riverbed scour that is reached during flood stage may be measured at times of normal or low flow despite the tendency of sediments to fill in scour holes as flow decreases. 
Methods for studying the extent of scour after infilling occurs fall into two categories--coring and remote geophysical methods. Although coring may yield accurate, quantitative information, it is slow, expensive, and generally cannot provide a continuous profile. Less expensive geophysical methods provide rapid, continuous, subbottom profiles with qualitative information about subbottom materials. With appropriate processing, interpretation, and correlation with test-hole or sampling data, some of these methods may also yield quant itative information about the physical properties of subbottom materials. Thus, the use of surface-geophysical methods minimizes the need for coring and sampling, and provides unique information about the water bottom and subbottom sediments.

\section{Purpose and Scope}

This report discusses the use of four surface-geophysical methods for analys is of riverbed scour at bridge piers, conducted by the U.S. Geological Survey, in cooperation with the Federal Highway Administration. These methods are: ground-penetrating radar and three seismic methods--black-andwhite fathometer, color fathometer, and tuned transducer. The use of seismic methods for mapping subbottom stratigraphy in rivers and lakes is well documented in the literature (Morrissey and others, 1985; Haeni, 1986b; Haeni, 1988; Reynolds and Williams, 1988). Ground-penetrating radar has also been used to map subsurface stratigraphy in lakes and on land (Wright, and others, 1984; Haeni and others, 1987). Each method has advantages and limitations and will be discussed in terms of theory, interpretation, and application to the study of riverbed scour at bridge piers.

\section{Study Area}

The Connecticut River is a 380-mile long water course which serves as a major outlet for runoff in New England. At Thompsonville, just north of Hartford, Connecticut, the average flow of the river from 1930 to 1960 was about $10,000 \mathrm{ft}^{3} / \mathrm{s}$ (cubic feet per second). However, the river often floods, increasing the flow to greater than 10 times the average (Ryder and others, 1981). Since 1935, there have been four spring floods in which the river rose more than $30 \mathrm{ft}$ (feet) above base level in Hartford (Be11, 1985), and the maximum flow was $282,000 \mathrm{ft}^{3} / \mathrm{s}$ on March 20, 1936 (Cervione and others, 1987). During June and July 1987, when the study was conducted, the flow of the Connecticut River in Thompsonville varied from $3,570 \mathrm{ft}^{3} / \mathrm{s}$ to $27,200 \mathrm{ft}^{3} / \mathrm{s}$ (M. A. Cervione, U.S. Geological Survey, written commun., 1987). The study focused on three bridges spanning the Connecticut River in Hartford, Connecticut. These bridges listed north to south are the Bulkeley Bridge, the Founder's Bridge, and the Charter Oak Bridge (fig. 1). 


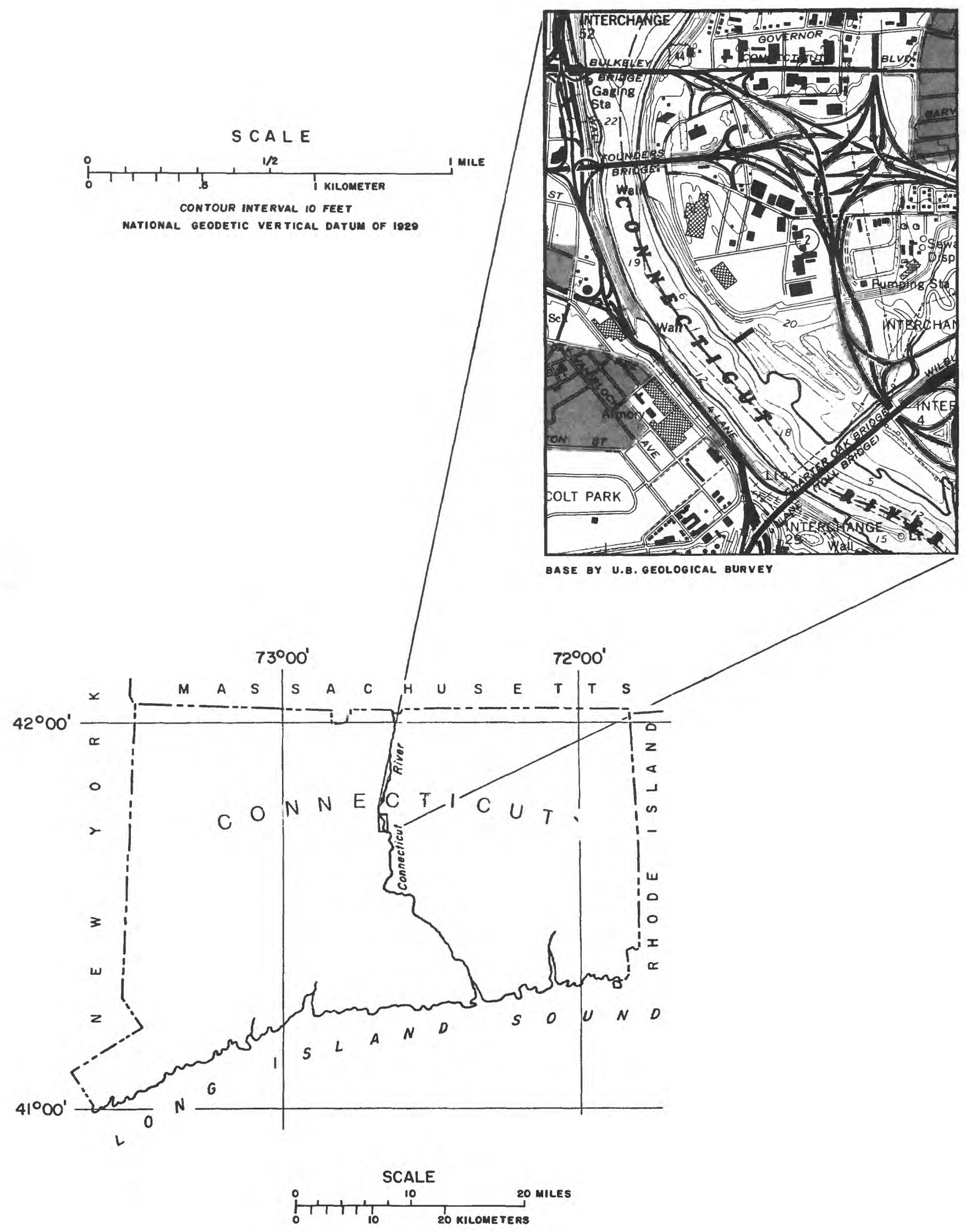

Figure 1.--The study area. 


\section{Acknowledgments}

The technical assistance and financial support of the Office of Research, Development, and Technology of the Federal Highway Administration, which made this study possible, is greatly appreciated.

\section{DESCRIPTION OF SURFACE-GEOPHYSICAL METHODS}

\section{Ground-Penetrating Radar}

Ground-penetrating radar can be used on land or in relatively shallow water (less than $20 \mathrm{ft}$ ) to obtain high-resolution, continuous, subsurface profiles. With this method, short, 80 to $1,000 \mathrm{mHz}$ (megahertz) electromagnetic pulses are transmitted into the subsurface by a transmitter located in the antenna, and energy reflected from subsurface interfaces is received. Interfaces are delineated where there are differences in electrical properties because of changes in the degree of saturation or compositional differences in subsurface materials. When the electromagnetic energy reaches a physical property interface between two layers or objects, some of the energy is reflected back to the surface, some is attenuated, and some is transmitted into deeper layers.

The reflected pulse is received at the antenna, and is sent, through the control unit, to a graphic recorder and a tape recorder. The two-way travel time in nanoseconds $\left(10^{-9}\right.$ seconds) is plotted and recorded. If the $\mathrm{Er}$ (relative dielectric permitivity) in a given medium is known or can be estimated or measured, the depth to each interface may be calculated. Relative dielectric permitivity is a ratio of the permitivity (ability to store an electrical charge) of a given medium to that of free space. Where the depth to a reflector is known from a test-hole or well, the relative dielectric permitivity may be calculated through the following equation:

$$
\mathrm{Er}=(\mathrm{t} / 2)^{2} \times(\mathrm{c} / \mathrm{d})^{2},
$$

where $\mathrm{Er}$ is relative dielectric permitivity (dimensionless ratio);

$t$ is two way-travel time, in seconds;

$C$ is speed of light in free space, equal to $9.835712 \times 10^{8}$ feet per second; and

$d$ is depth to the reflector, in feet. 


\section{Seismic Systems}

Seismic systems operate through the transmission and reception of acoustic waves through the subsurface and water column. Part of the seismic signal is reflected back to the surface where a change in acoustical impedence occurs at an interface between two layers or objects in the subsurface. Acoustical impedence $(Z)$ is defined as the product of the density of a medium (e), and the velocity of the sound within the medium (V). The degree to which an interface reflects a seismic signal is a function of its reflection coefficient (RC) which is defined as follows:

$$
R C=\frac{z_{2}-z_{1}}{z_{2}+z_{1}}=\frac{e_{2} V_{2}-e_{1} V_{1}}{e_{2} V_{2}+e_{1} V_{1}}=\frac{A r}{A i}
$$

where $\quad R C$ is the reflection coefficient of the interface;

$z_{1}, z_{2}$ is the acoustical impedence of layers one and two;

Ar, $A i$ is the amplitude of the reflected and incident signals;

$e_{1}, e_{2}$ is the densities of layers one and two; and

$v_{1}, v_{2}$ is the velocity of sound in layers one and two.

The average velocity of sound in shallow, saturated, unconsolidated glacial outwash, silt, and clay in Connecticut is $5,075 \mathrm{ft} / \mathrm{s}$ (feet per second) (Haeni, 1986a). Assuming no salinity, the velocity of sound in the water column is $4,888 \mathrm{ft} / \mathrm{s}$ at an average water temperature of $22^{\circ} \mathrm{C}$ (degrees Celsius) (Sheriff, 1984). In this study, the average velocity of sound through both mediums was assumed to be $5,000 \mathrm{ft} / \mathrm{s}$.

Three seismic methods were used to examine riverbed scour at bridge piers: black-and-white fathometer, color fathometer, and tuned transducer. A major variable which distinguishes these methods from one another is the frequency of the seismic signal. Lower-frequency signals achieve better penetration of the subbottom with poorer resolution of subbottom features. Higher-frequency signals have better resolution, but may afford little or no penetration (Sylwester, 1983).

\section{Black-and-White Fathometer}

A black-and-white fathometer, model $X-15 B$, manufactured by Lowrance Incorporated, operating at a signal frequency of $200 \mathrm{kHz}$, was used in the study. At this frequency, the system had a resolution of a few inches and did not penetrate the river-bottom materials. It is a useful tool for defining existing scour holes, but it does not penetrate most sediments, and, therefore, will not show whether infilling has occurred. The sound 
If the relative dielectric permitivity of a medium has been calculated, or estimated from published data, the depth to a given reflector may be calculated through the following equation:

$$
d=V_{m} t / 2 \text {, }
$$

where $V m$, the radar-wave velocity, is equal to $c / E r^{1 / 2}$.

The velocity of radar waves is $0.11 \mathrm{ft} / \mathrm{ns}$ (feet per nanosecond) in fresh water (Geophysical Survey Systems Inc., 1987) and estimates, calculated from published relative dielectric permitivities, range from 0.17 $\mathrm{ft} / \mathrm{ns}$ (Morey, 1974) to $0.23 \mathrm{ft} / \mathrm{ns}$ (Wright and others, 1984) for sand saturated with fresh water. The radar-wave velocity calculated in this study, through comparison of ground-penetrating-radar records with measured depths was $0.18 \mathrm{ft} / \mathrm{ns}$. Other properties of subsurface materials, such as density and grain size, may also be determined by examining the strength, coherency, and character of the return pulses. Thus, a qualitative interpretation of the physical properties of subsurface materials, and a quantitative depth determination may be obtained.

Ground-penetrating radar seldom penetrates more than $100 \mathrm{ft}$ into the subsurface (Wright and others, 1984), and, in highly conductive material, it may only penetrate a few feet (0lhoeft, 1984). The resolution of this method is less than $2 \mathrm{ft}$, depending on the operating frequency, and it is, therefore, well suited for the distinction of sedimentary structures and buried objects near the surface. The penetration depth of groundpenetrating radar depends on the electrical properties of the material through which the pulse will be propagated. Highly conductive (low resistivity) materials, such as clay minerals, severely attenuate radar signals. Similarly, radar is ineffective where sediments are saturated with or overlain by salt water or other conductive fluids. Fresh water also attenuates the radar signal and, generally, limits the use of radar to sites overlain by less than $20 \mathrm{ft}$ of water.

For this study, an SIR 80 radar system built by Geophysical Survey Systems Incorporated was used. Either a single $80-\mathrm{mHz}$ antenna was used as a transceiver, or two $80-\mathrm{mHz}$ antennas were used, one as a high-powered transmitter and the other as a receiver. In general, the best results were obtained using the two-antenna combination, although some increase in side echo was observed near bridge piers. This interference was only a significant problem within $5 \mathrm{ft}$ of the piers. Ground-penetrating radar is unique among the geophysical methods used in this study because it uses electromagnetic energy to penetrate the subsurface. The other geophysical methods use seismic waves of various frequencies.

1/ The use of trade and firm names in this report is for identification purposes only and does not constitute endorsement by the U.S. Geological Survey. 
source for this instrument is a transducer, a few inches in diameter, which is mounted on the bottom of the boat. The black-and-white fathometer is easy to operate and a hard-copy record of the water-bottom profile is obtained. It is very useful for obtaining accurate measurements of water depth, and generally is unaffected by side echo from bridge piers.

The black-and-white fathometer was most useful in conjunction with the other geophysical systems. It provided accurate information on water depth and water-bottom morphology that was clear and easy to interpret. The black-and-white fathometer also aided in interpreting the geophysical data obtained with other methods. For example, side echo from the piers, on the records obtained with the other systems, could be easily identified by comparing these records to the black-and-white fathometer records.

\section{Color Fathometer}

The color fathometer used in this study was a variable-frequency (20 to $100 \mathrm{kHz}$ ) seismic system, model $\mathrm{HE}-730$, manufactured by $\mathrm{Si}$-Tex Incorporated, that digitized the reflected signal and displayed a color image on a cathode-ray tube. This system has a resolution of a few inches and penetration of 0 to $20 \mathrm{ft}$ of subsurface materials, depending on the selected frequency. It can be used to distinguish some physical properties of surficial and subsurface sediments. This system measures the ratio of amplitudes of the reflected and incident signals, in decibels, at the sediment-water interface and at shallow interfaces in the subsurface. $A d b$ (decibel) is defined as 20 times the logarithm of the amplitude ratio or the reflection coefficient:

$$
\begin{gathered}
20 \log (\operatorname{Ar} / A i) \\
\text { or } \\
20 \log (R C)
\end{gathered}
$$

Color fathometers distinguish between different interfaces by assigning different colors to changes in the amplitude of the reflected signal. The system used in this study assigned a color change to every 6-db change in amplitude ratio or reflection coefficient. Note that a 6 -db change is equivalent to a reflection coefficient of 2 or an amplitude ratio of $2: 1$.

Because the color fathometer delineates decibel changes in the reflected signal, which are directly related to reflection coefficients, certain physical properties of the bottom and subbottom materials may be calculated or estimated. A number of studies have shown that reflection coefficients are linearly related to bulk density, porosity, and median grain size of marine sediments (Faas, 1969; Hamilton, 1970; Parrott and others, 1980). When properly calibrated, the color fathometer may be used to define and identify sedimentary facies. Additional work is necessary before any quantitative determinations of physical properties of fluvial sediments can be made from the color-fathometer records. However, qualitative information is obtained from these records, and it appears likely that direct quantitative interpretations are possible. 
Although no hard copies of the records were obtained, data were stored on high-density, chromium-dioxide cassette tapes for playback and processing. Because the data displayed on a color monitor are not easily reproducible, the color-fathometer records in this paper are represented as black-and-white photographs.

\section{Tuned Transducer}

The tuned transducer used in this study has a range of operating frequencies from 3.15 to $14 \mathrm{kHz}$ (kilohertz), and was manufactured by Ferranti O.R.E., Incorporated. The resolution of the tuned transducer system ranges from a few inches to a few feet depending on the selected frequency. In fine-grained material, up to $100 \mathrm{ft}$ of subbottom penetration may be achieved, whereas subbottom penetration may be limited to a few feet in coarser materials. Changes in frequency may be made to optimize penetration and resolution depending on the objectives of a particular study.

Multiple-tuned transducers may also be used in various combinations to meet specific needs. For example, the use of parallel transducers of equal frequency may be used to narrow the beam angle of the outgoing signal. Separate transmitter-receiver combinations may also be used to enhance the seismic record in shallow-water areas. It also is possible to traverse the same section at two distinct frequencies so that shallow as well as intermediate-depth results may be obtained.

\section{ASSESSMENT OF RIVERBED SCOUR}

The black-and-white fathometer, ground-penetrating radar, tuned transducer, and color fathometer were used to evaluate scour at three bridges spanning the Connecticut River in Hartford, Connecticut, and the results of the different techniques were compared. All piers were numbered from east to west, starting with the first pier that was in the water at the time of the study. Riverbed scour was associated with nearly every pier in the study. The geometry and size of scour holes varied, depending on the pier location and position in relation to the direction and magnitude of the current. Cross sections were run in both directions upstream from the piers, and lateral sections were run on both sides of a number of selected piers. Ground-penetrating radar, color fathometer, and tuned transducer surveys were all run at the Charter Oak and Bulkeley Bridges along with the $200 \mathrm{kHz}$ black-and-white fathometer. Founder's Bridge sections were surveyed with ground-penetrating radar and black-and-white fathometer only. In a 11 cases, existing scour was clearly observed, and, at several sites, the depth to a deeper scour surface, formed during a previous flood event, could be determined. 


\section{Bulkeley Bridge}

The Bulkeley Bridge, the northernmost bridge in the study area, is the Connecticut River crossover for Interstate 84 between East Hartford and Hartford. A total of eight bridge piers were in the water at the time of the study. The piers are $100 \mathrm{ft}$ long and $20 \mathrm{ft}$ wide with pointed ends, and are evenly spaced, $150 \mathrm{ft}$ apart, across the entire span. The average water depth $100 \mathrm{ft}$ upstream from the piers was $8 \mathrm{ft}$. Figure 2 shows a crosssectional ground-penetrating-radar record from a section $15 \mathrm{ft}$ upstream from this bridge. The scour holes were 6 to $8 \mathrm{ft}$ deeper than the adjacent waterbottom (water-bottom base leve 1 ), and 60 to $70 \mathrm{ft}$ wide in a cross sectional view. Piers 1 through 7 had scour holes that were directly in front of them in a cross-sectional view. However, the scour associated with pier 8 was to the east of the pier, possibly due to the direction of the current, which was flowing east to west at this point. The depth of the scour generally increased from east to west as might be expected, since the river is curving, and the current is greatest on the western side.

Infilling was observed on the cross-sectional radar records at piers 3 , 4,5 , and 6. In each case, this infilling consisted of 2 to $5 \mathrm{ft}$ of soft sediments overlying a harder, more reflective surface. The deeper interfaces are interpreted as old scour surfaces, and may consist of gravel and pebbles that settled into the scour holes during flood stages of the river, on top of the eroded surface of glaciolacustrine clays.

The focus of this study is on the application of various geophysical methods to the evaluation of riverbed scour at bridge piers. With that end in mind, the results of each geophysical method at pier 5 of the Bulkeley Bridge are compared. Each method was useful in describing the existing geometry of the scour hole at this pier. Eight feet upstream from the pier, a scour hole was observed to be 6 to $8 \mathrm{ft}$ deeper than the adjacent river bottom, $60 \mathrm{ft}$ wide, and symmetrical about the center of the pier. This scour hole extended $30 \mathrm{ft}$ upstream from the pier. A deeper scour hole, adjacent to the pier near its downstream end, was also ident if ied. The water reached a depth of $22 \mathrm{ft}, 12 \mathrm{ft}$ below water-bottom base leve 1 , in this hole. Downstream from the pier, the water became shallow, 2 to 3 feet deep, at a topographic rise. Relief of the water bottom between the scour hole adjacent to the pier and the top of the sandbar exceeded $20 \mathrm{ft}$ over a horizontal distance of $80 \mathrm{ft}$.

The 200-kHz black-and-white fathometer quickly and accurately defined the depth and geometry of the existing scour. However, virtually no penetration of the subbottom materials was achieved with this instrument. Qualitative information about the reflectivity of the bottom materials could be derived by observing whether or not multiple reflections were present (in relatively hard bottoms, multiples would be present), and by observing the tone of the record at the sediment-water interface. No information regarding the thickness or extent of infilling could be ascertained. A lateral 200-kHz fathometer record run $6 \mathrm{ft}$ east of pier 5 , and a cross section run $8 \mathrm{ft}$ upstream from pier 5 are shown in figure 3 . The cross 
LGव $N I$

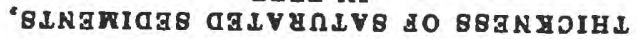

도
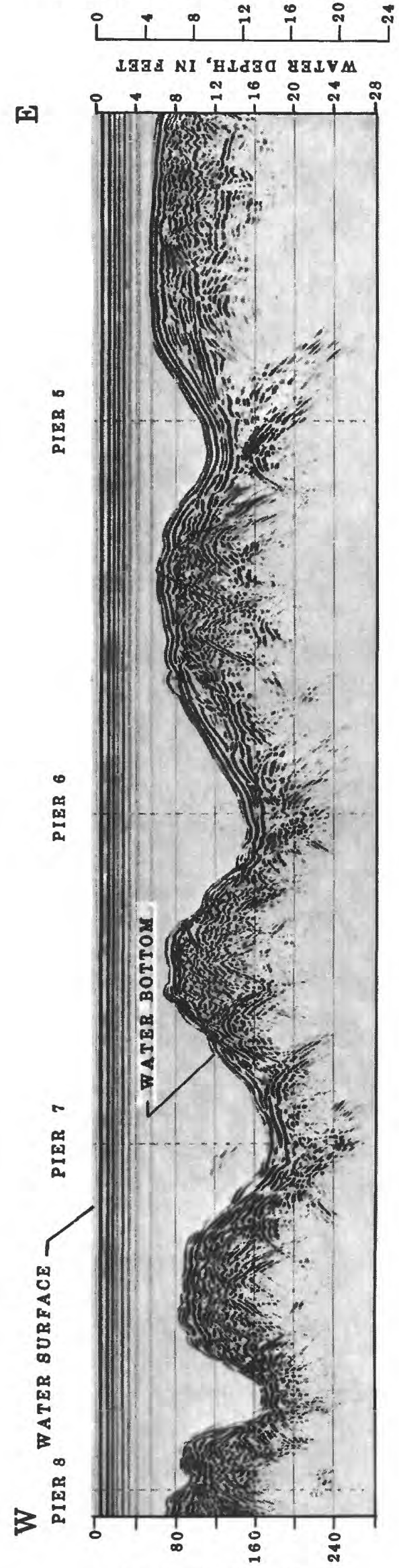

SANOOIBONVN NI

'马KIL TSAVYL LVM INO
แล NI

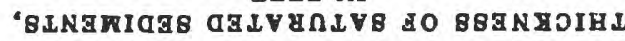

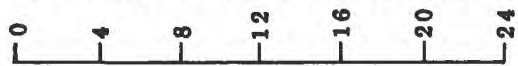

IUG NI HIdGa gaLM

ar

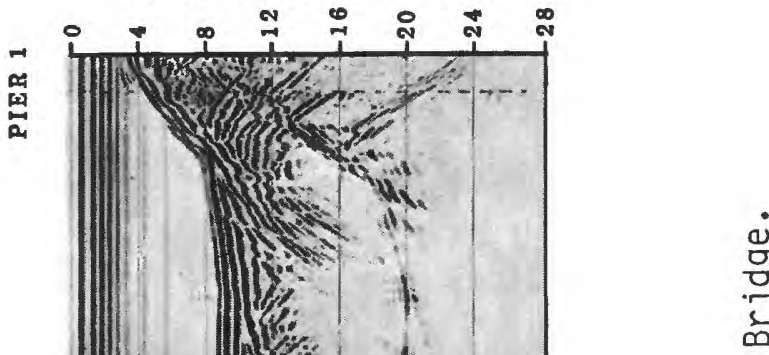

客

a)

$\frac{2}{\stackrel{一}{\Xi}}$

옴

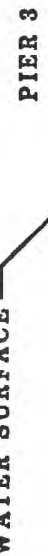

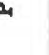

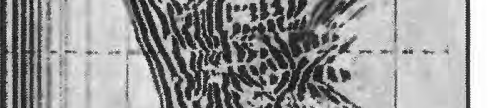

1) ygata

悉

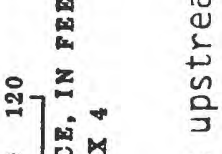

$8-\frac{0}{2}$

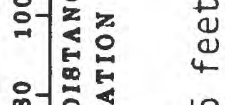

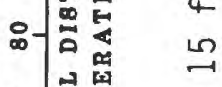

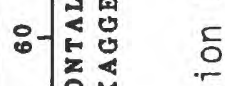

에네

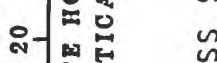

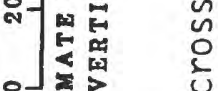

高



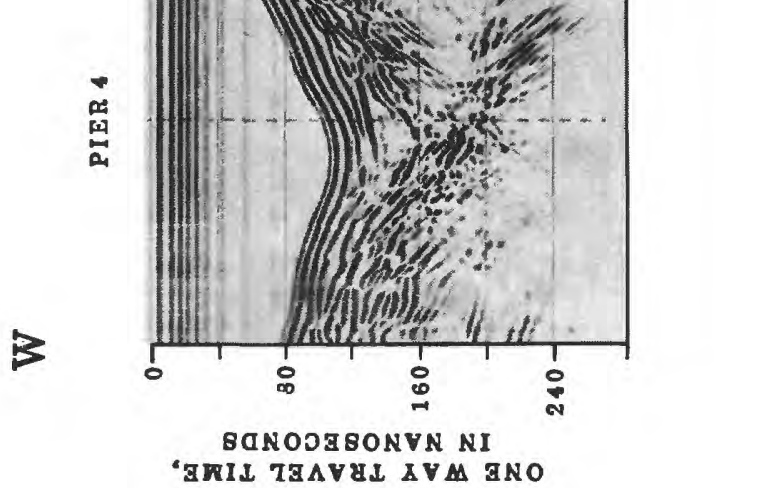



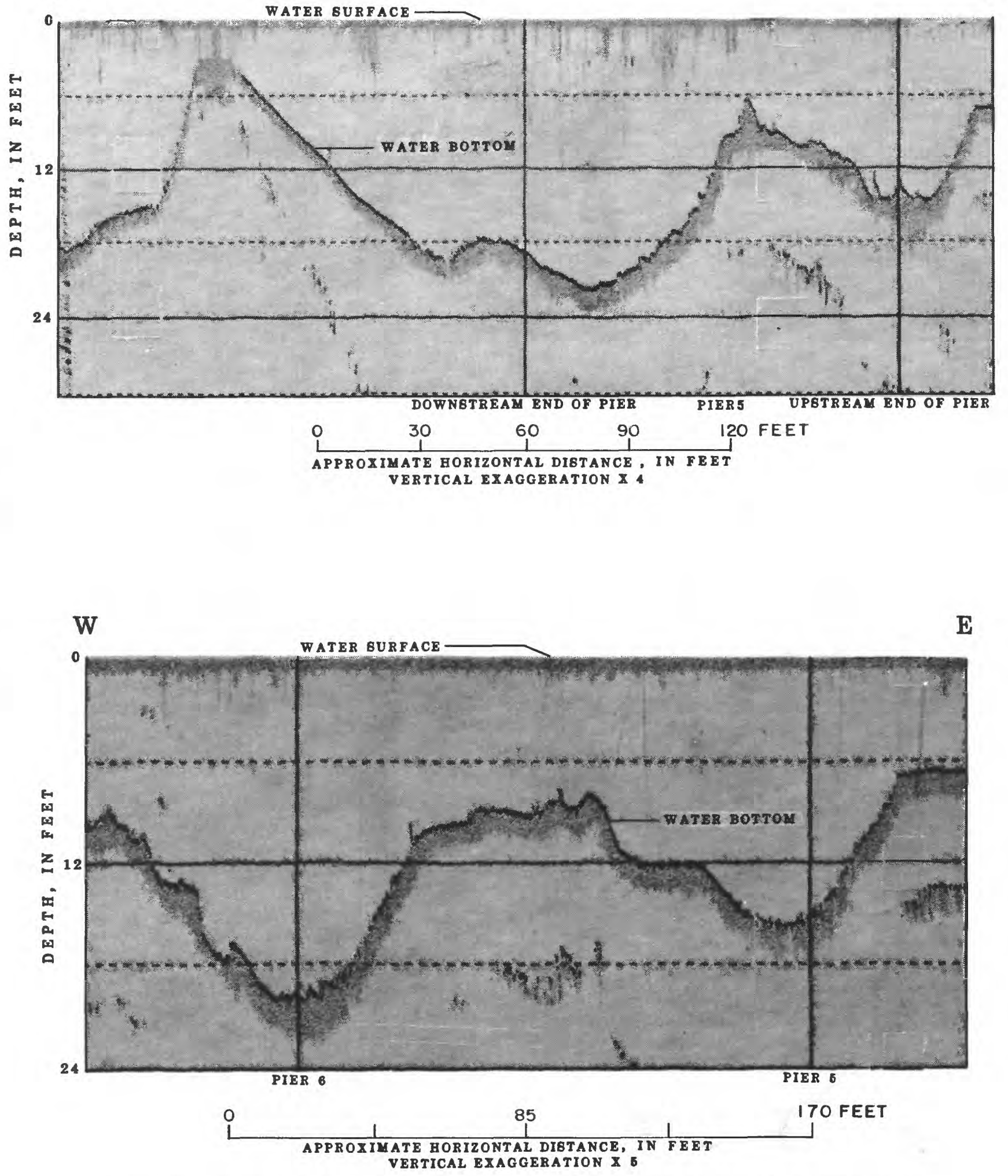

Figure 3.-- A 200-kilohertz black-and-white fathometer cross section ( 8 feet upstream from the pier) and lateral section ( 6 feet east of the pier) at pier 5 of the Bulkeley Bridge. 
section correlates with the tuned transducer section shown in figure 6 and not with the ground-penetrating-radar records in figures 2 and 4 , which were run $7 \mathrm{ft}$ further upstream. Multiples are apparent on the black-and-white fathometer records, indicating a relatively reflective water bottom. The existing scour geometry is clearly defined, and the sediment-water interface is distinct, also indicating a reflective water bottom.

Ground-penetrating radar proved to be effective for detecting subbottom layers at this pier. An interpreted cross-sectional radar record run $15 \mathrm{ft}$ upstream from pier 5 is shown in figure 4 . Infilling of the scour hole is evident on the radar record, and the infilled material is probably fine-grained sediments deposited in the hole during periods of normal or low streamflow. The apparent thickness of material deposited in the center of this hole is 4 to $5 \mathrm{ft}$. It is important to note that the shapes of reflectors on time sections are controlled, in part, by variations in the thickness of, and velocity of wave propagation through overlying layers. Because the velocity of radar waves increases from fresh water to saturated sediments, the topography of the water bottom is positively superimposed on subbottom interfaces on ground-penetrating-radar records. Because of this phenomenon, a flat-lying layer beneath a scour hole may appear as a depression on a radar record. For this reason, the slope of the subbottom reflector on the radar record, is greater than the true slope of the old scour surface. The interpretation of the radar section, shown in figure 4 , takes this factor into account, and shows the true topography of the old scour surface.

A lateral radar section run $8 \mathrm{ft}$ to the east of pier 5 is shown in figure 5. Three to $5 \mathrm{ft}$ of infilled material is again apparent upstream from the pier. In the deeper scour hole, on the eastern-downstream side of the pier, no post-scour deposition is evident on the radar record. In this area, however, the water depth was approaching the limit for radar use and there was virtually no penetration of the subbottom sediments by the radar signal. Some side-echo signals reflected from the pier masked some of the subbottom signals at distances within 3 to $5 \mathrm{ft}$ of the pier. However, at greater distances, there was little side-echo interference. Water-bottom multiple radar signals were not observed at this pier, because of the relative depth of the water column and the physical properties of the sediments.

The 14-kHz tuned transducer also defined the geometry of the scour hole at this pier. A record of a cross section $8 \mathrm{ft}$ upstream from the pier, and a lateral section $10 \mathrm{ft}$ to the east of the pier are shown in figures 6 and 7 respectively. Post-scour deposition upstream from the pier is apparent on the cross-sectional record and is interpreted to be 3 to $4 \mathrm{ft}$ of uncompacted, fine-grained sediments, which correlates with the radar reflection at this pier. In the lateral view, the geometry of the existing scour was clearly defined. No infilling was evident in the scour hole adjacent to the eastern-downstream side of the pier, but the infilling upstream from the pier was apparent. The depth of the water column was not a problem for the tuned transducer, and side echos were observed only when the transducer was within $5 \mathrm{ft}$ of the pier. 

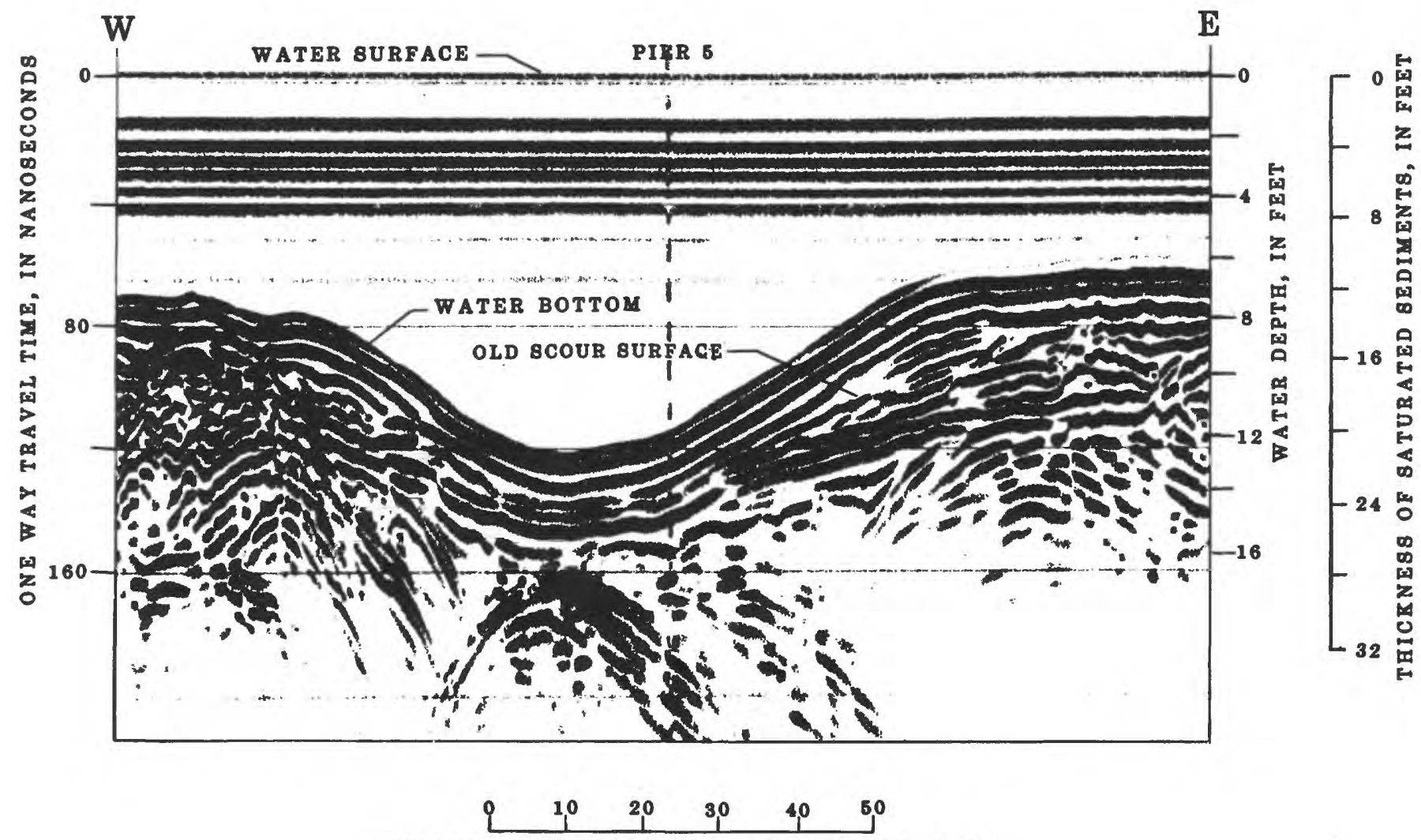

APPROXIMATE HORIZONTAL DISTANCE, IN FEET

VERTICAL EXAGGERATION X
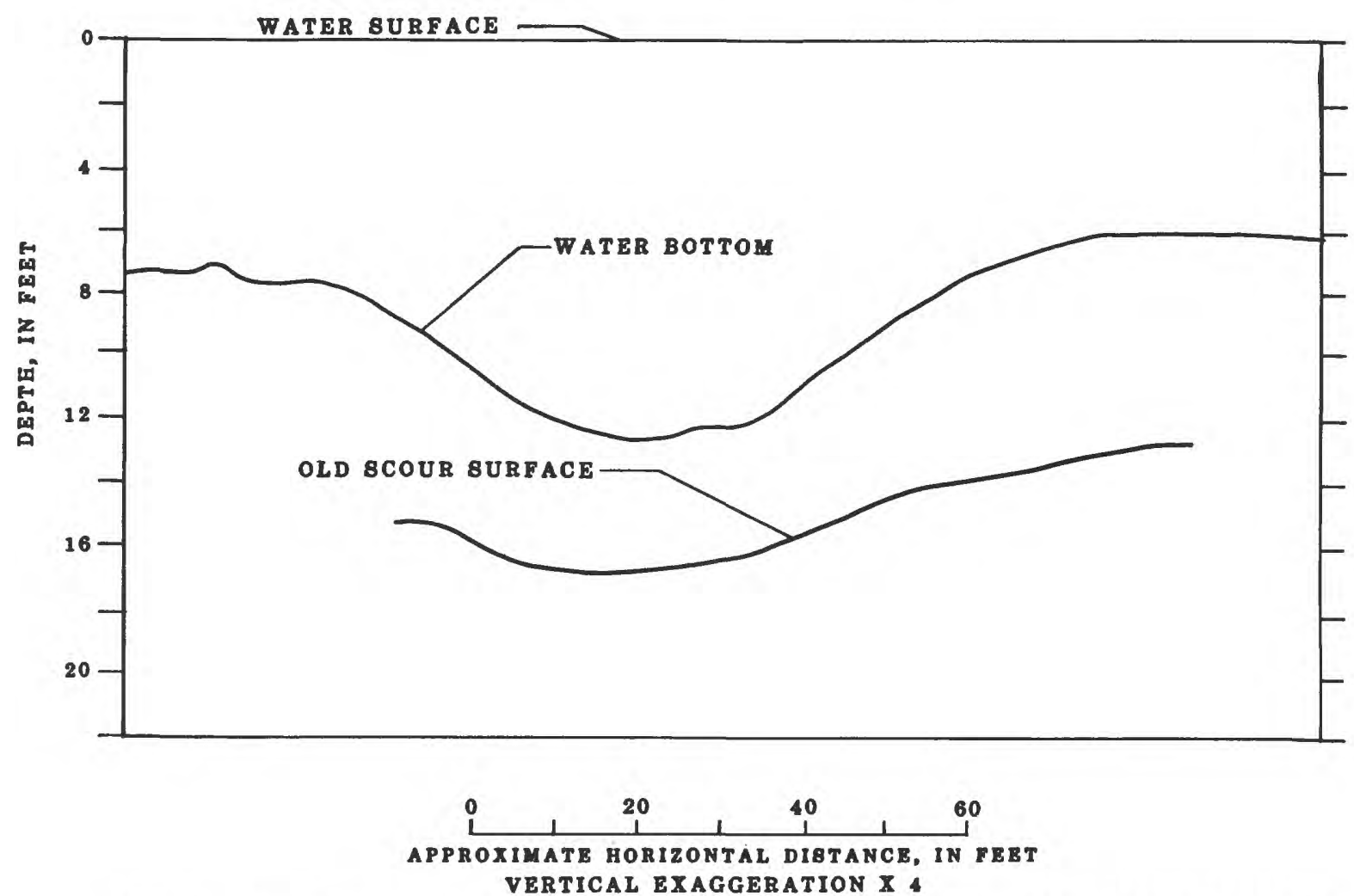

Figure 4.-- Ground-penetrating-radar cross section and interpretation 15 feet upstream from pier 5 of the Bulkeley Bridge. 
Ja्व $\mathrm{NI}$

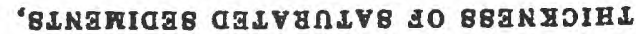
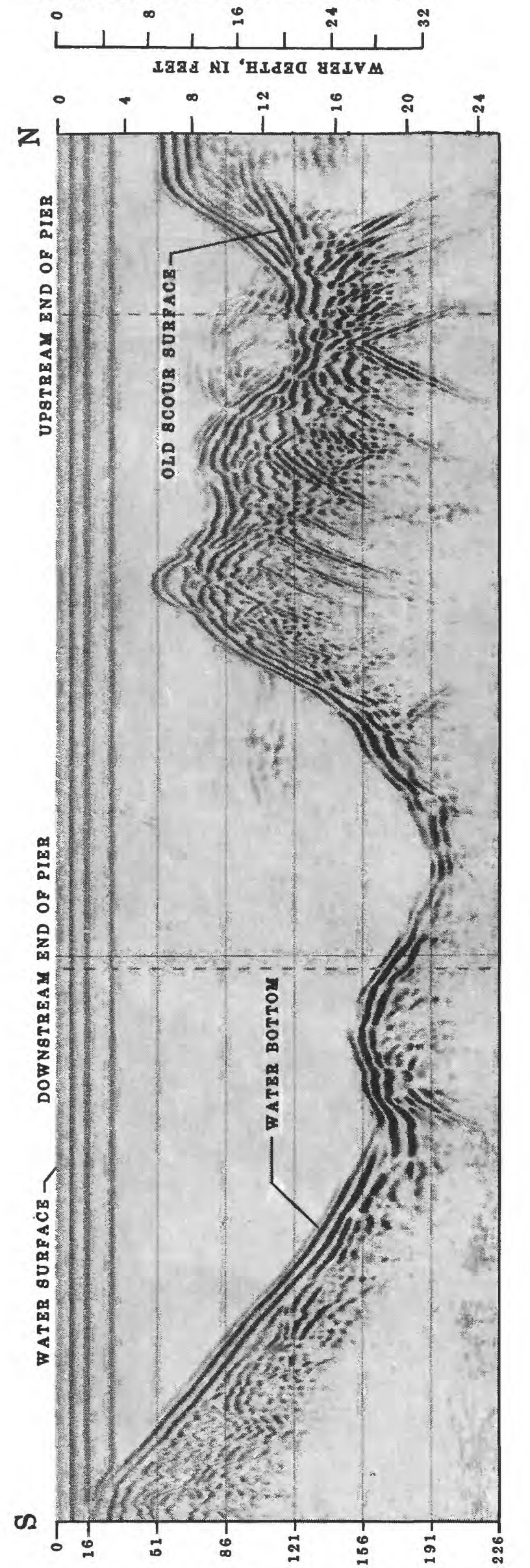

|7-

$\frac{\dot{0}}{8}$

$\frac{\vec{\alpha}}{\frac{a}{a}}$

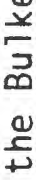

岳

เ

$\frac{1}{2}$

4

4

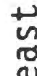

a

$\frac{0}{4}$

$+$

$+$

¿

$\infty$

등

$\stackrel{0}{0}$

in

西

$\stackrel{0}{\square}$

용

只

$+$

$\frac{1}{2}$

임

$\frac{1}{0}$
$\frac{1}{3}$
0
0

!

ปัง

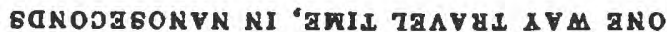




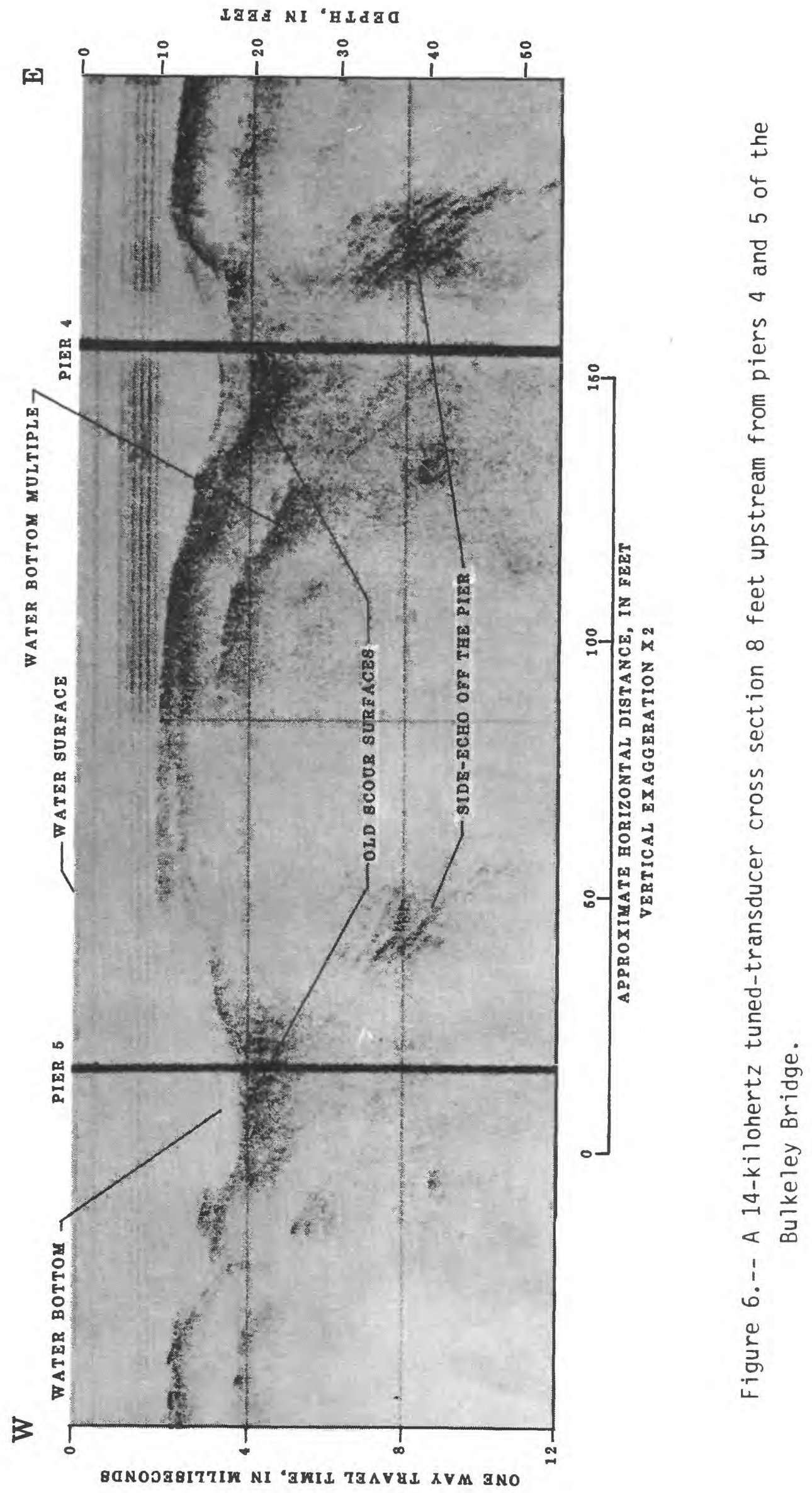




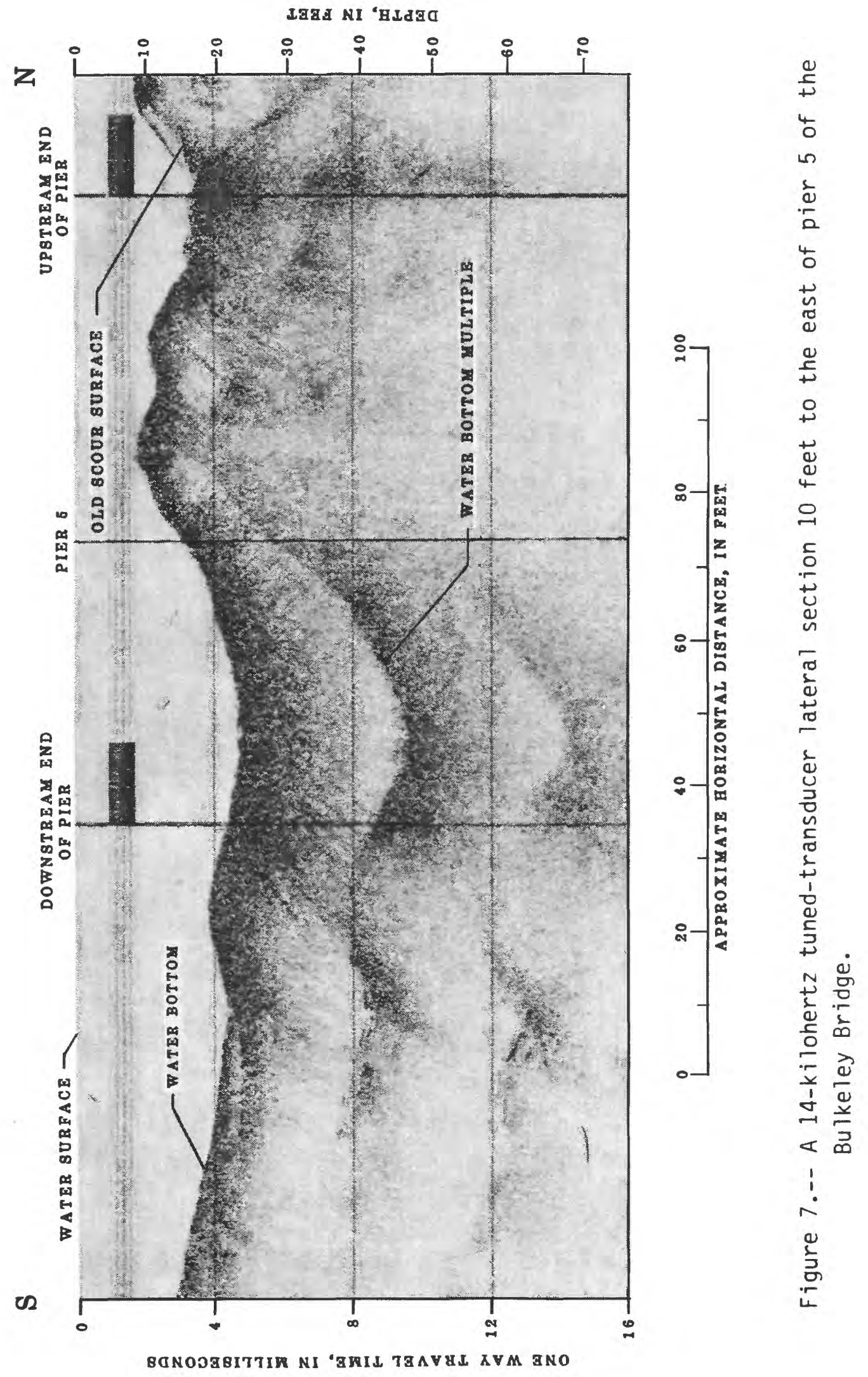


The color fathometer, operating at a signal frequency of $20 \mathrm{kHz}$, delineated the geometry of the existing riverbed scour and infilling of scour holes at this site. Black-and-white photographs of a cross-sectional color fathometer record $12 \mathrm{ft}$ upstream from pier 5 and a lateral record $8 \mathrm{ft}$ to the east of pier 5 are shown in figures 8 and 9 respectively. In a cross-sectional view, 4 to $5 \mathrm{ft}$ of soft sediments were observed to overlie a harder layer at the center of this scour hole. Infilling is evident in the lateral section, both upstream from and adjacent to the pier. The extent of infilling adjacent to the pier is estimated to be 0.5 to $1 \mathrm{ft}$. As in the case of the tuned transducer, the depth of the water column was not a concern. Side echoes were evident on the records, but this interference was only observed within $5 \mathrm{ft}$ of the pier and could be readily ident ified. Multiple reflections were observed on the color record, but with penetration limited to only a few feet, they did not pose a problem.

\section{Charter Oak Bridge}

The Charter Oak Bridge is the southernmost bridge in the study area. It serves as the crossover for Connecticut Route 15, $1 \mathrm{mi}$ (mile) south of Hartford. There were two rectangular piers with pointed ends, $100 \mathrm{ft}$ long and $25 \mathrm{ft}$ wide, in the water at the time of the study, and riverbed scour was observed at both. The largest scour hole in the study area was located at pier 1 of this bridge. Upstream from this pier, the scour hole extended $18 \mathrm{ft}$ below the water-bottom base level. There was considerably less scour at pier 2 because of the presence of boulders and debris from a pier that collapsed during the construction of the bridge (James Matula, Connecticut Department of Transportation, written commun., 1988). The typical parabolic reflections associated with point reflectors (boulders) are evident on all of the geophysical records at pier 2.

A cross-sectional ground-penetrating-radar record, $10 \mathrm{ft}$ upstream from the piers, is shown in figure 10. Note that the depth of the water at pier 1 approaches the 1 imit of radar penetration in fresh water at this site. The geometry of the existing scour was defined on the radar record, but no subbottom penetration was achieved. A 200-kHz black-and-white fathometer record from the same line, shown in figure 11, yields similar information regarding the geometry of this scour hole, but again, no subbottom penetration was achieved and presence of any infilling could not be detected.

A black-and-white photograph of a $20 \mathrm{kHz}$, lateral color-fathometer record run $8 \mathrm{ft}$ to the east of pier 1 is shown in figure 12, and figure 13 shows a black-and-white photograph of a cross section run $10 \mathrm{ft}$ upstream from the piers. The soft bottom and fine-grained subbottom sediments at this bridge site resulted in greater than $20 \mathrm{ft}$ of penetration for the color fathometer. The cross-sectional record clearly defines the scour-hole geometry. The scour hole is symmetrical around the pier, with a maximum depth $18 \mathrm{ft}$ below the water-bottom base level. About $5 \mathrm{ft}$ of soft sediments deposited since the scour occurred was present in the cross-sectional view. 


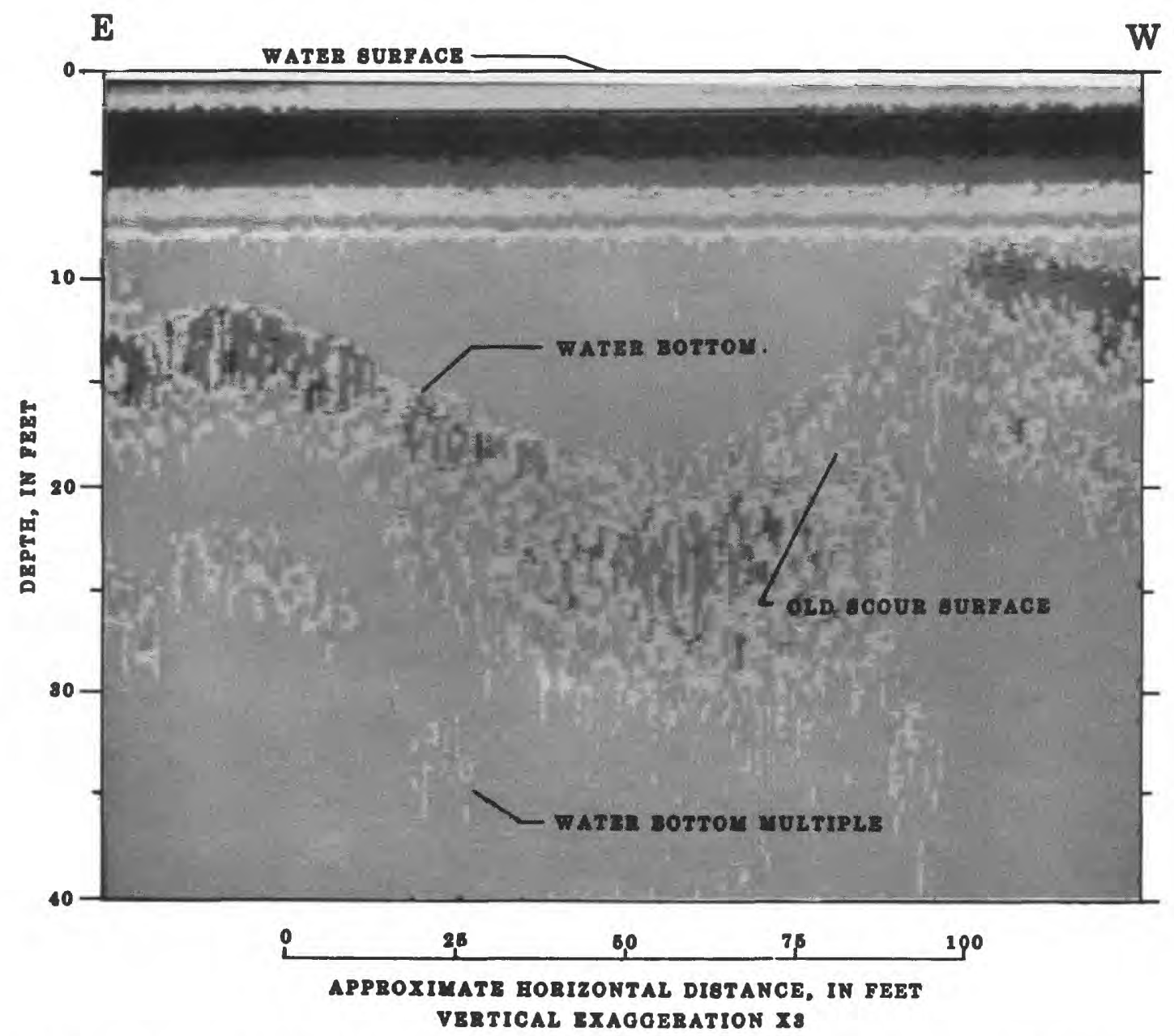

Figure 8.-- A 20-kilohertz color-fathometer cross section 12 feet upstream from pier 5 of the Bulkeley Bridge

(black-and-white photograph). 

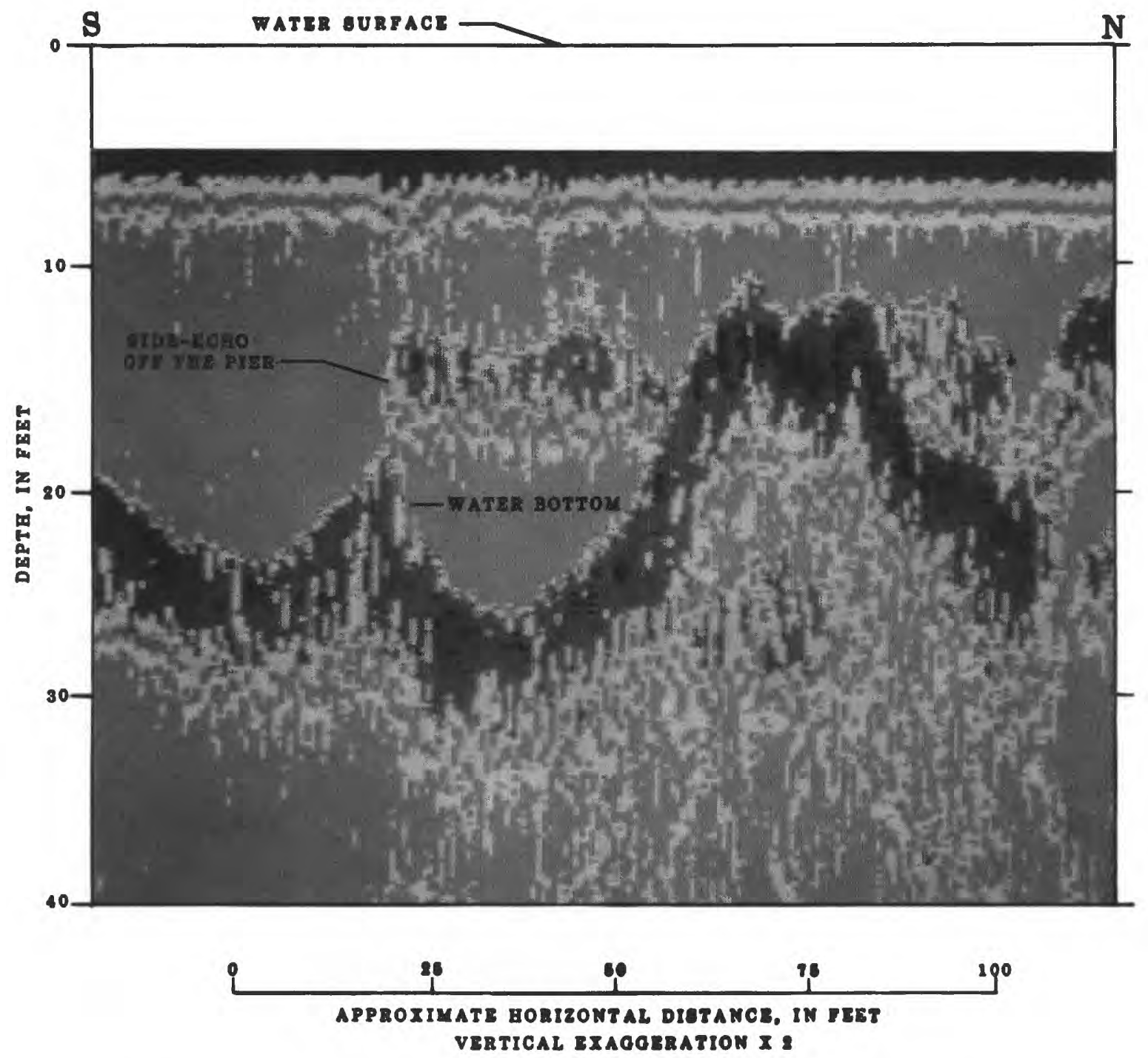

Figure 9.-- A 20-kilohertz color-fathometer lateral section 8 feet to the east of pier 5 of the Bulkeley Bridge

(black-and-white photograph). 


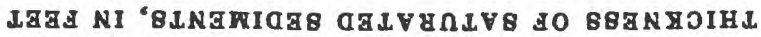

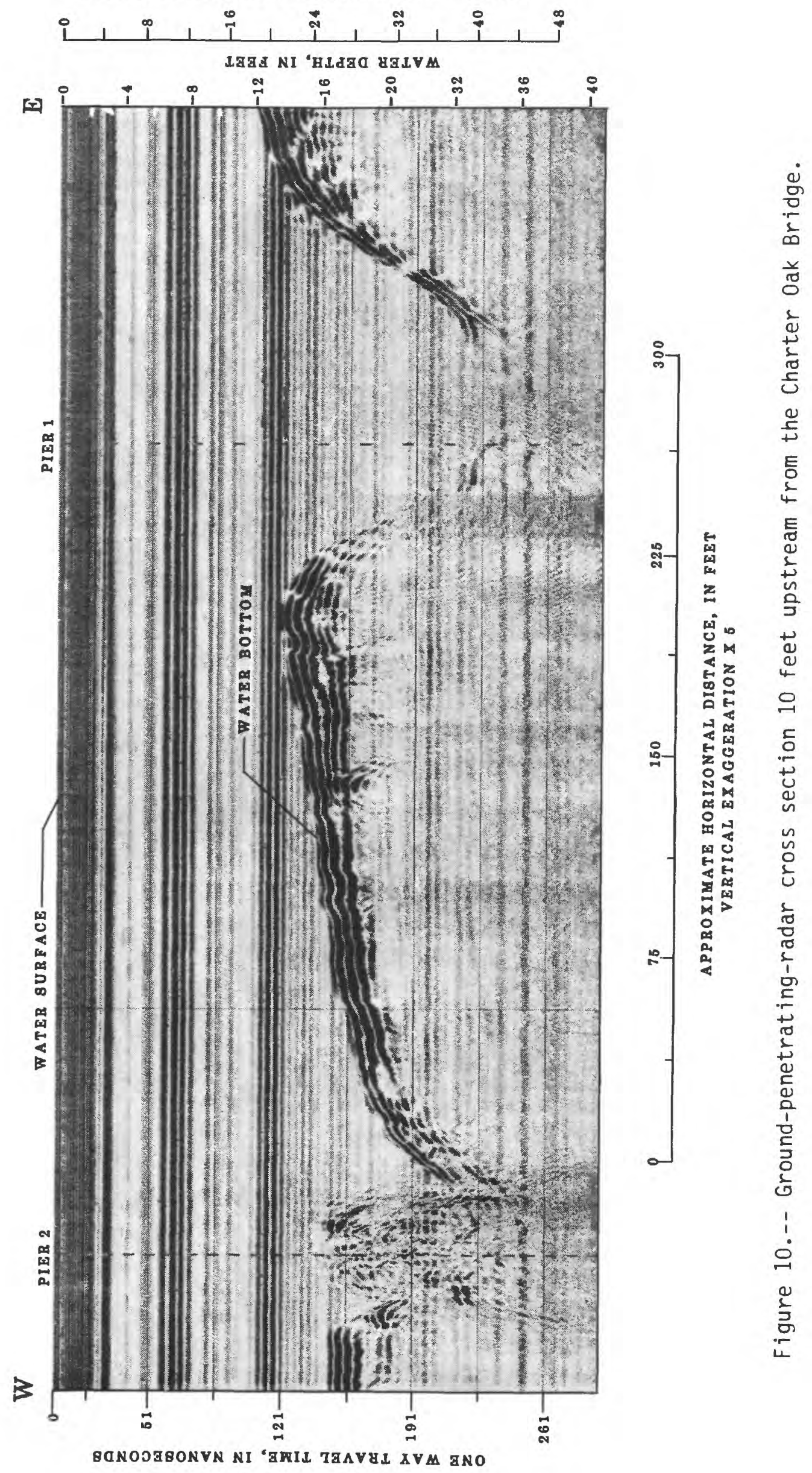




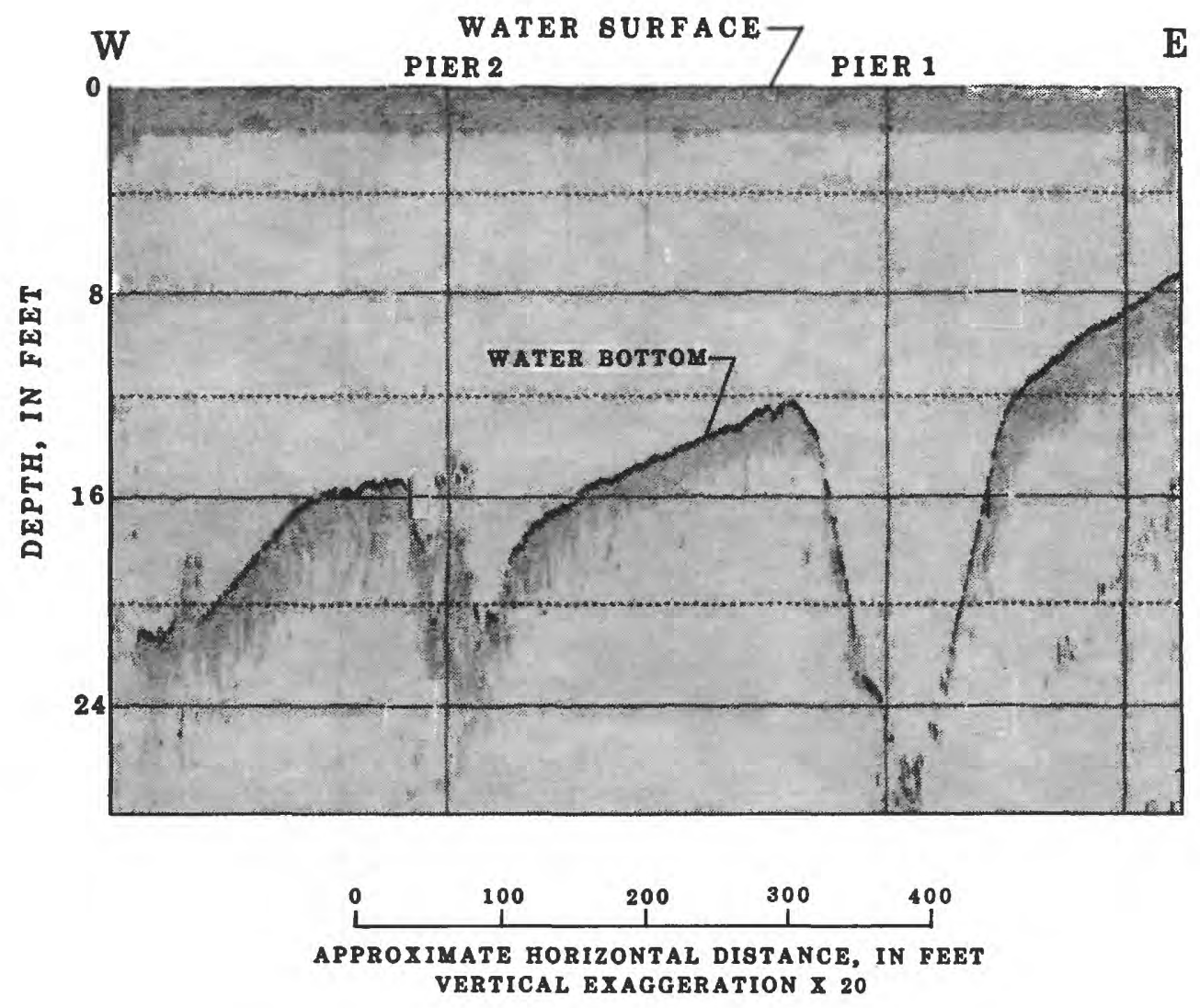

Figure 11.-- A 200-kilohertz black-and-white fathometer cross section 10 feet upstream from the Charter Oak Bridge. 

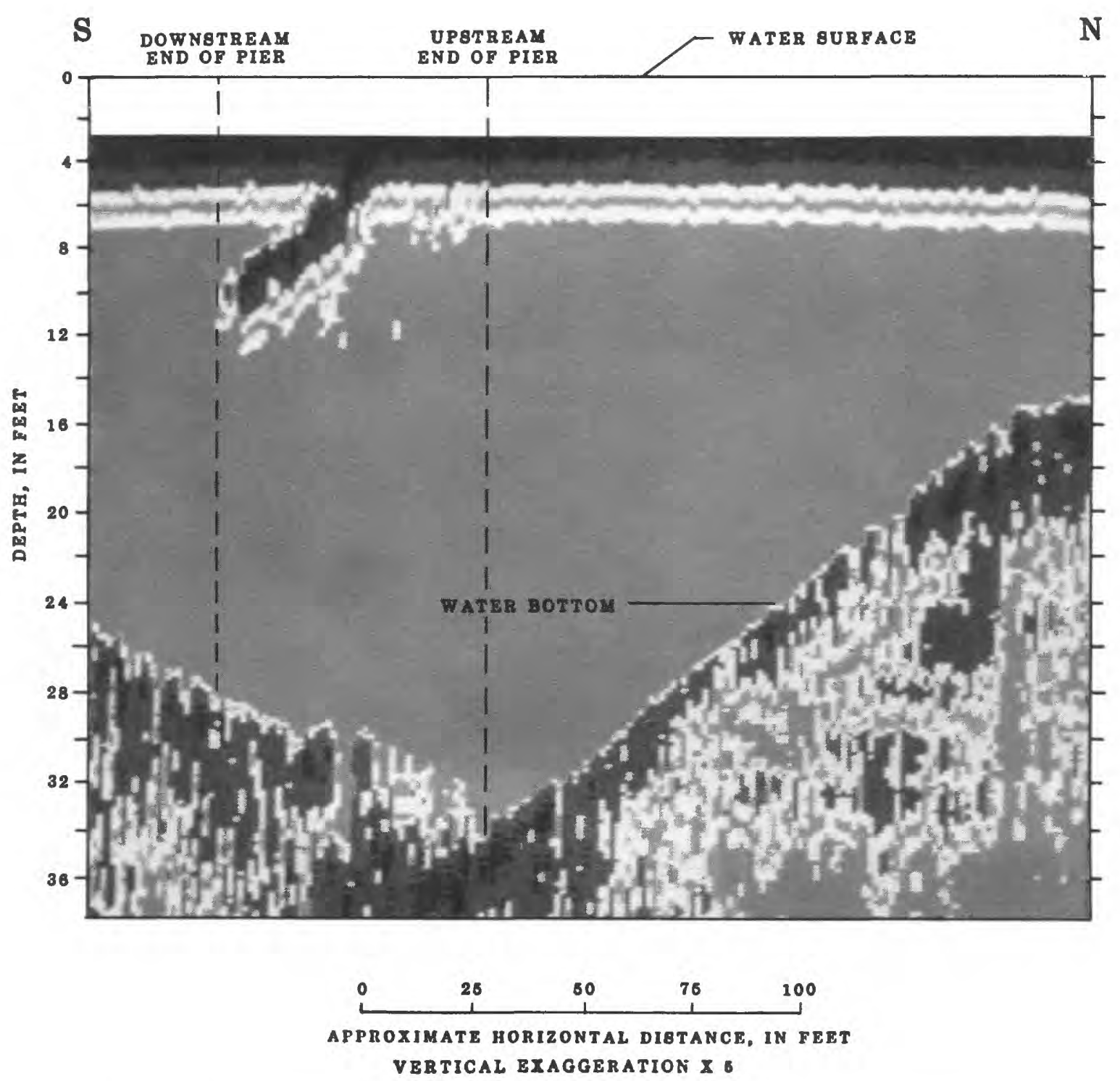

Figure 12.-- A 20 kilohertz color-fathometer lateral section 8 feet to the east of pier 1 of the Charter Oak Bridge (black-and-white photograph). 

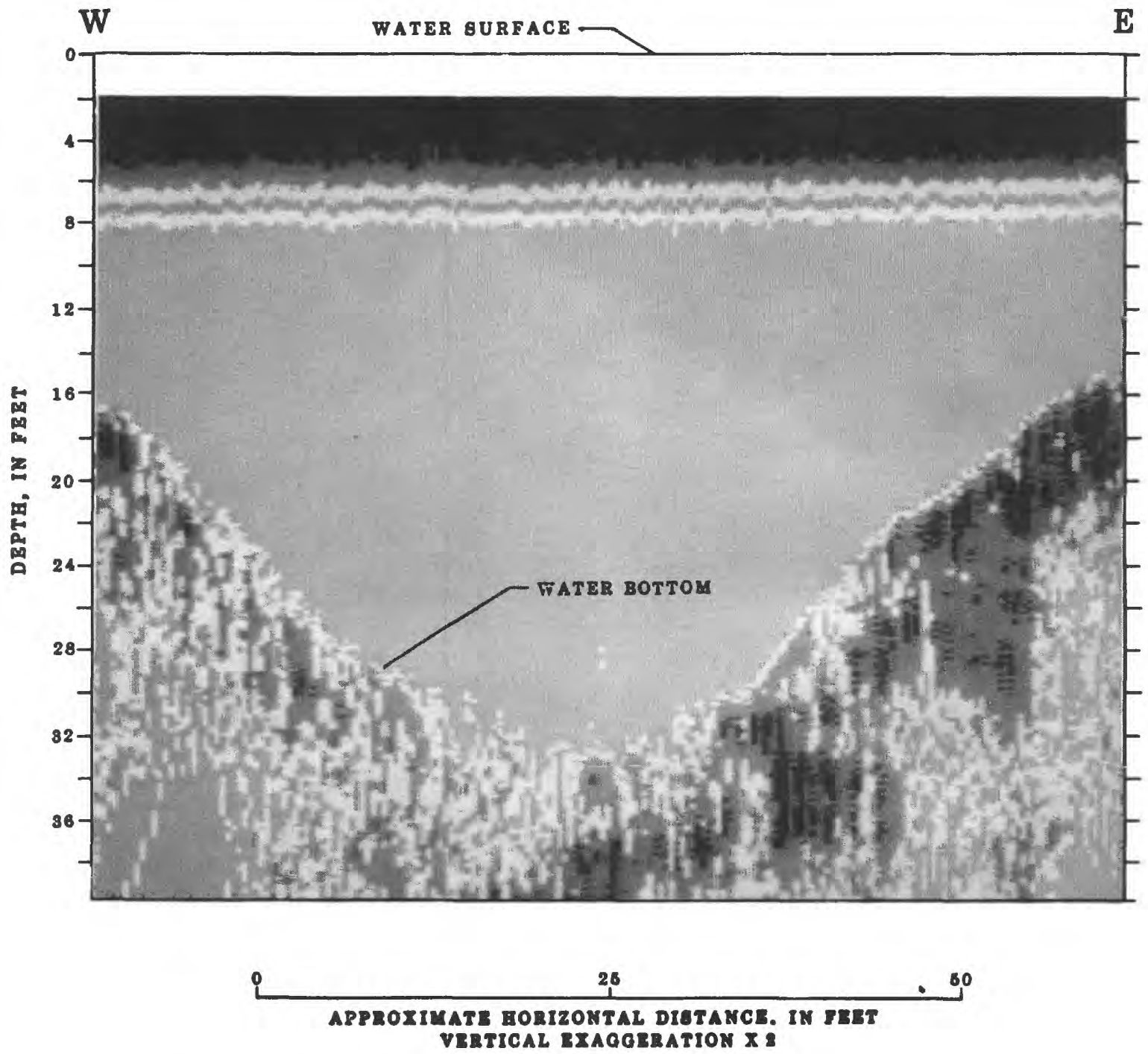

Figure 13.-- A 20-kilohertz color fathometer cross section 10 feet upstream from the Charter Oak Bridge (black-and-white photograph). 
In the lateral view, the geometry of the scour hole at the upstream end of the pier was defined and about $5 \mathrm{ft}$ of infilling by post-scour sediments was again detected.

A cross-sectional, 14-kHz tuned-transducer record, from a section $10 \mathrm{ft}$ upstream from the piers, is shown in figure 14 . Greater than $20 \mathrm{ft}$ of subbottom penetration was achieved. The record defines the scour-hole geometry and shows 4 to $5 \mathrm{ft}$ of infilled material, and slump deposits on the western side of the scour hole. Reflectors are present within this slumped material that intersect laminar glaciolacustrine sediments. A record of a lateral section $8 \mathrm{ft}$ east of pier 1 , also run at $14 \mathrm{kHz}$, is shown in figure 15. Again, greater than $20 \mathrm{ft}$ of subbottom penetration was achieved. The geometry of the scour hole was clearly defined, and $5 \mathrm{ft}$ of infilled material was evident in the upstream side of the hole. However, no postscour sedimentation was evident in the deepest part of this scour hole.

\section{Founder's Bridge}

The Founder's Bridge, located between the Bulkeley and Charter Oak Bridges connects Interstate 86 between Hartford and East Hartford. There were four rectangular piers, $90 \mathrm{ft}$ long and $20 \mathrm{ft}$ wide, in the water at the time of the study. Pier 1 , near the east bank, was located in water too shallow to be navigable. Only ground-penetrating radar and black-and-white fathometer records were obtained at this site. Ground-penetrating radar achieved greater than 10 feet of subbottom penetration, whereas the blackand-white fathometer did not penetrate the river bottom. A groundpenetrating-radar cross section run $8 \mathrm{ft}$ upstream from this bridge is shown in figure 16. Scour, $8 \mathrm{ft}$ upstream from pier 4 , extended $10 \mathrm{ft}$ below waterbottom base level and no post-scour sediments were detected. The scour hole at pier 3 extended $8 \mathrm{ft}$ below water-bottom base level, and $4 \mathrm{ft}$ of infilled material is evident on the radar record. No scour was apparent at pier 2, where the water was $25 \mathrm{ft}$ deep. The lack of scour at pier 2 may be attributable to the eastward bend in the Connecticut River, that concentrates flow along the west bank. This was the only pier in the study where there was no significant scour.

\section{CONCLUSIONS}

Each of the geophysical methods investigated was useful in assessing riverbed scour at bridge piers. However, each method had characteristic advantages and disadvantages. Consequently, some methods may not be suited for use at a particular site. In most cases, a combination of geophysical methods was the most effective means of assessing scour conditions.

Ground-penetrating radar was the most useful method in shallow water. It provided information about existing scour-hole geometry and the extent of infilling of scour holes by post-scour sediments. This geophysical method 


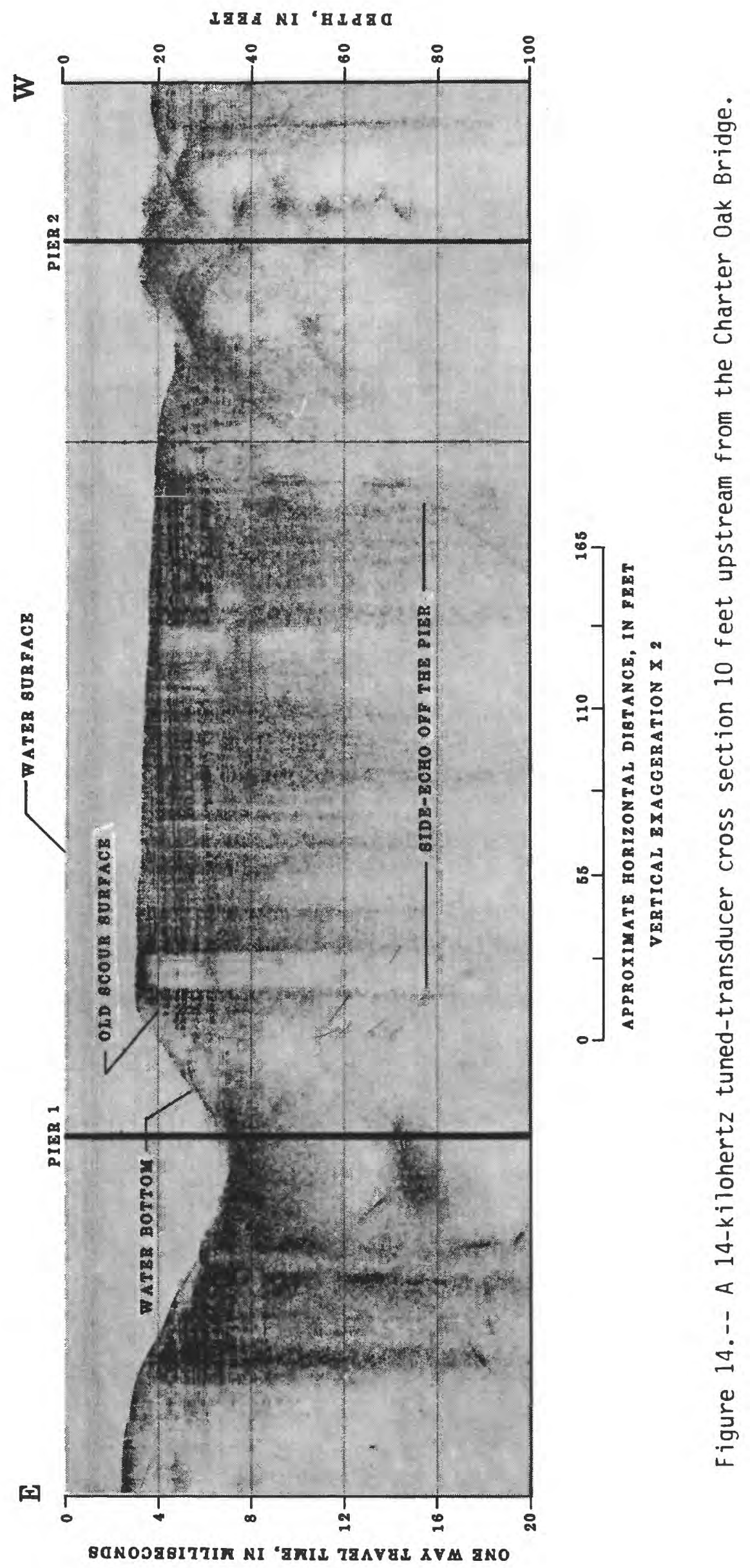




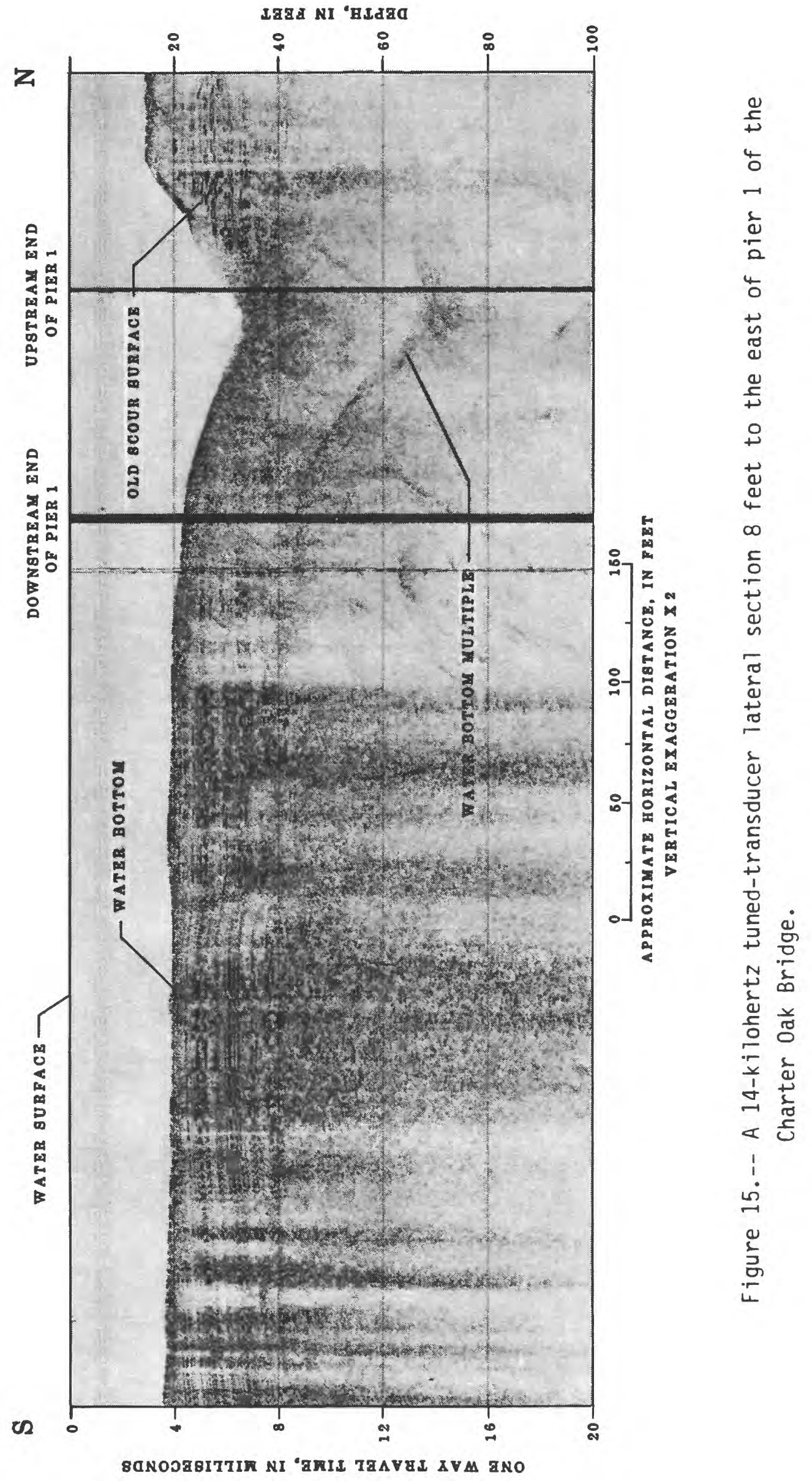




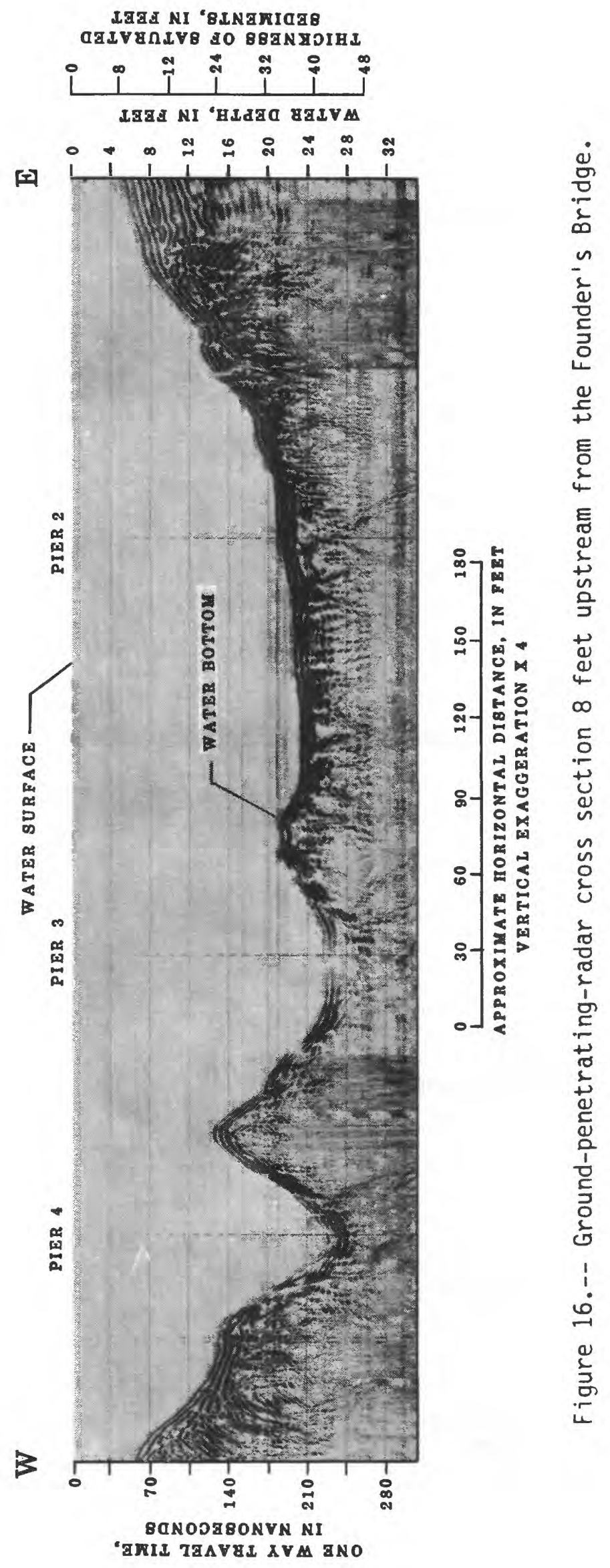


is 1 imited by the depth of water and the electromagnetic and physical properties of subbottom sediments and the water. It should be noted that radar can also be used in dry streambeds to detect scour holes filled by post-scour sediments.

The $200-\mathrm{kHz}$ black-and-white fathometer was useful in determining scourhole geometry and depth. However, no penetration of the water-bottom was achieved with this instrument. The black-and-white fathometer is most most useful when run in conjunction with other geophysical equipment. It is easy to operate and provides reliable information about water depth without interference from side echos.

The color fathometer was effective in providing information about scour-hole geometry and infilling of scour holes. It also provided qualitative information about the physical properties of bottom and subbottom sediments. Infilling of scour holes by soft sediments above more compact, reflective sediments was detected with this instrument. The color fathometer is most effective in water greater than $5 \mathrm{ft}$ deep and in soft or fine-grained, uncompacted sediments.

The tuned transducer was able to define existing and refilled scour holes. It is most advantageous in water greater than $5 \mathrm{ft}$ deep; at shallower depths, multiple water-bottom reflections may obscure the subsurface data. The tuned transducer may achieve subbottom penetration of $50 \mathrm{ft}$ or more depending on sediment properties such as compactness and gra in size. At $14 \mathrm{kHz}$, resolution of a few inches may be achieved.

The characteristics of each geophysical method are summarized in table 1. Although each method has advantages and disadvantages, no single one proved to be ideal for studying riverbed scour. The degree to which any one method is advantageous for a study depends on several factors. In situations where radar is ineffective, such as in salt water or deep fresh water, the color fathometer or tuned transducer may provide excellent results. Conversely, in shallow fresh water, radar generally provides the best information. In some cases, such as boulder-strewn streambeds, none of these methods will be successful. In most cases, a combination of these geophysical methods can be used to provide the most comprehensive and accurate information on riverbed scour at bridge piers. The geophysical surveys may be conducted during periods of normal or low streamflow, without the need for extensive coring or direct sampling. 
Table 1.-- Summary of the geophysical methods used to assess riverbed scour at bridge piers

GROUND-PENETRATING RADAR

FREQUENCY $80-1,000 \mathrm{mHz}$.

PENETRATION Less than 20 feet in fresh water.

Less than 80 feet in resistive material (depending on frequency).

A few feet in highly conductive materials.

RESOLUTION

A few inches to a few feet

(depending on frequency).

LIMITATIONS Limited penetration in salt water, clays, and other conductive materials.

Multiple reflections may obscure data.

Signal may be scattered due to cobbles and boulders.

Difficult to operate and interpret.

Signal is highly attenuated in the water column.

ADVANTAGES Defines subbottom materials and stratigraphy.

Good for use on land and in shallow water.

Penetration through organic material.

High resolution in shallow subsurface.

No multiples on land.

A hard copy of data is obtained.

APPROXIMATE

COST

OPERAT ION
$\$ 20,000-\$ 60,000$.

Operates through the transmission of electromagnetic energy into the subsurface, and the subsequent reception of energy reflected at interfaces between layers or objects of differing electrical properties.
BLACK-AND-WHITE FATHOMETER

$200 \mathrm{kHz}$.

None in typical marine sediments.

1 - 5 feet in very soft sediments.

A few inches.

No definition of subbottom materials.

Good definition of sediment-water interface.

Accurate assessment of water depth

Easy to operate.

A hard copy of data is obtained.

$\$ 400-\$ 3,000$.

Utilizes a small transducer (a few inches in diameter) to transmit high frequency acoustic pulses, and receive signals ref lected at interfaces between layers or objects of differing acoustical properties.
BRIDGE SCOUR In shallow, fresh water or on land. STUD IESENVIRONMENT

BRIDGE SCOUR STUDIES-

EXPECTED

RESULTS
May define existing and filled holes.

G'jod definition of shallow stratigraphy.
In shallow or deep water.

May define existing holes.

Accurate depth assessment. 
FREQUENCY $20-100 \mathrm{kHz}$.

PENETRATION 0 - 20 feet, depending on frequency and subbottom material.

Little penetration in coarsegrained sediments.

RESOLUTION A few inches.

LIMITATIONS Minimum water depth of 5 feet.

Will not penetrate gases/gassy organics.

Mult iple reflections may obscure data.

Does not provide a hard copy record.

Little penetration in coarse-grained sediments.

ADVANTAGES May penetrate conductive materials. Variable frequency.

May be used to define subbottom materials and stratigraphy.

Good in deep water.

May indicate some physical properties of sediments

(ie. density, porosity, grain size).

APPROXIMATE $\$ 2,000-\$ 5,000$.

COST

OPERATION

BRIDGE SCOUR STUDIESENVIRONMENT

BRIDGE SCOUR STUDIESEXPECTED RESULTS
$3.5-14 \mathrm{kHz}$.

0 - 100 feet depending on frequency and subbottom material.

Little penetration in coarse-grained sediments.

A few inches to a few feet (depending on frequency)

Minimum water depth of $5-10$ feet

(depending on bottom materials)

Will not penetrate gases/gassy organics.

Difficult to operate.

Little penetration in coarse-grained sediments.

May penetrate conductive materials. Variable frequency.

May be used to define subbottom materials and stratigraphy.

Good in deep water.

A hard copy of data is obtained.

$\$ 20,000-\$ 30,000$.

Operates with a variable frequency transducer (about 4 inches in diameter) which transmits acoustic pulses and receives reflected signals from interfaces between layers or objects of differing acoustical properties.

Cassette recordings of data may be obtained.

In greater than 5 feet of water.

May define existing and filled holes.

May vary frequency to opt imize penetration or resolution.
May vary frequency to opt
penetration or resolution.

May indicate some physical properties of sediments. 


\section{REFERENCES}

Be 11. Michae 1, 1985, The face of Connecticut: State Geological and Natural History Survey of Connecticut, Bul letin 110, p. 26-31.

Cervione, M. A., Weiss, L. A., Bohr, J. R., and Bingham, J. W., 1987, Water resources data Connecticut water year 1985: U.S. Geologicai Survey Water-Data Report CT-85-1, 279 p.

Faas, R. W., 1969, Analysis of the relationship between acoustic reflectivity and sediment porosity: Geophysics, v. 34, no. 4, p. 546-553.

Geophysical Survey Systems Incorporated, 1987, Operation Manual, Subsurface Interface Radar SIR System 8: Hudson, New Hampshire, p. $18-20$.

Haeni, F. P., 1986a, Application of seismic-refraction techniques to hydrologic studies: U.S. Geological Survey Open-File Report 84-746, $144 \mathrm{p}$.

-..--, 1986b, Application of continuous seismic-reflection methods to hydrologic studies: Groundwater, v. 24, no. 1, p. 23-31.

-.-.-, 1988, [in press], Evaluation of the continuous seismic-reflection method for determining the thickness and lithology of stratified drift in the glaciated northeast, in Randall, R. D. and Johnson, A. I., eds., Regional Aquifer Systems of the United States; Northeastern Glacial Aquifer: American Water Resources Association Monograph, ser. no. 11.

Haeni, F. P., McKeegan, D. K., and Capron, D. R., 1987, Ground penetrating radar study of the thickness and extent of sediments beneath Silver Lake, Berlin, and Meriden, Connecticut: U.S. Geological Survey Water-Resources Investigations Report 85-4108, $19 \mathrm{p}$.

Hamilton, E. L., 1970, Reflection coefficients and bottom losses at normal incidence computed from Pacific sediment properties: Geophysics, v. 35, no. 6, p. 995-1004.

Hopkins, G. R., Vance, R. W., and Kasraie, B., 1980, Scour around bridge piers: Federal Highway Administration Report No. FHWA-RD-79-103, $131 \mathrm{p}$.

Jarrett, R. D. and Boyle, J. M., 1986, Pilot study for collection of bridge scour data: U.S. Geological Survey Water-Resources Investigations Report $86-4030,89$ p. 
Morey, R. M., 1974, Continuous subsurface profiling by impulse radar: Proceedings Engineering Foundation Conference on Subsurface Exploration for Underground Excavation and Heavy Construction, American Society Civil Engineers, p. 213-232.

Morrissey, D. J., Haeni, F. P., and Tepper, D. H., 1985, Continuous seismicreflection profiling of glacial-drift deposits on the Saco River, Maine and New Hampshire: National Water Well Association 2nd Annual Eastern Regional Groundwater Conference, Portland, Maine, 1985, p. 277-296.

Murillo, J. A., 1987, The scourge of scour: Civil Engineering, July 1987, p. 66-69.

0lhoeft, G. R., 1984, Application and limitations of ground penetrating radar: in Conference Proceedings, 54th Annual International Society for Exploration Geophysics Meeting December 2-6, 1984, Atlanta, Georgia, p. 147.

Parrott, D. R., Dodds, D. J., King, L. H., and Simpk in, P.G., 1980, Measurement and evaluation of the acoustic reflectivity of the sea floor: Canadian Journal of Earth Science, v. 17, p. 722-737.

Reynolds, R. J., and Williams, J. H., 1988 [in press], Continuous marine seismic-reflection survey of glacial deposits along the Susquehanna, Chemung, and Chenango Rivers, south-central New York and north-central Pennsylvania, in, Randall, A. D. and Johnson, A. I., eds., Regional Aquifer Systems of the United States; Northeastern Glacial Aquifer: American Water Resources Association Monograph, ser. no. 11 .

Ryder, R. B., Thomas, M. P., and Weiss, L. A., 1981, Water resources inventory of Connecticut, part 7, upper Connecticut River basin: Connecticut Water Resources Bullet in 24, $78 \mathrm{p}$.

Sheriff, R. E., 1984, Encyclopedic dictionary of exploration geophysics: Tulsa Ok lahoma, Society of Exploration Geophysics, p. 270.

Sylwester, R. E., 1983, Single-channel, high-resolution seismic-reflection profiling, a review of the fundamentals and instrumentation: in Geyer, R. A., ed., Handbook of Geophysical Exploration at Sea: Boca Raton, Florida, CRC Press, p. 77-122.

Wright, D. L., Olhoeft, G. R., and Watts, R. D., 1984, Ground penetrating radar studies on Cape Cod: National Water Well Association-Environmental Protection Agency Conference on Surface and Borehole Geophysical Methods in Ground Water Investigations, San Antonio, Texas, 1984, p. 666-680. 